\title{
Comment on the letter of the Society of Vertebrate Paleontology (SVP) dated April 21, 2020 regarding "Fossils from conflict zones and reproducibility of fossil-based scientific data": the importance of private collections
}

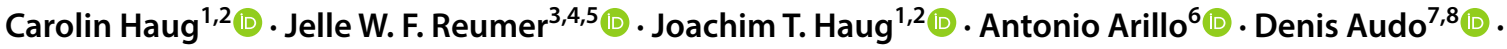 \\ Dany Azar ${ }^{9}$ (1) - Viktor Baranov ${ }^{1}$ (1) . Rolf Beutel ${ }^{10}$ (1) Sylvain Charbonnier ${ }^{11} \cdot$ Rodney Feldmann $^{12} \cdot$ Christian Foth $^{13}$ (1) .

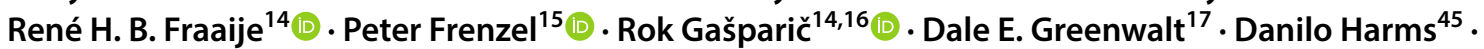

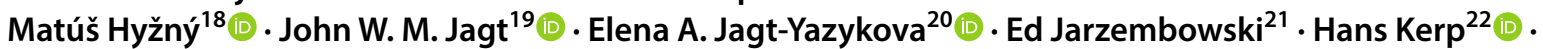

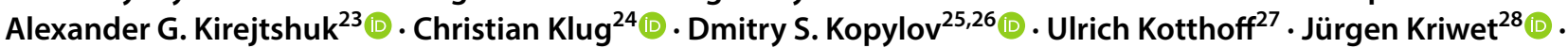 \\ Lutz Kunzmann ${ }^{29}$ (1) Ryan C. McKellar ${ }^{30}$ - André $\mathrm{Nel}^{31}$. Christian Neumann ${ }^{32}$ (1) Alexander Nützel $\mathbf{l}^{2,33,34}$ (1) . \\ Vincent Perrichot ${ }^{35}$ (D) Anna Pint ${ }^{36}$. Oliver Rauhut ${ }^{2,33,34}$. Jörg W. Schneider ${ }^{37,38(1)} \cdot$ Frederick R. Schram $^{39}$ (1).

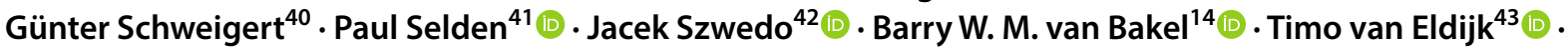

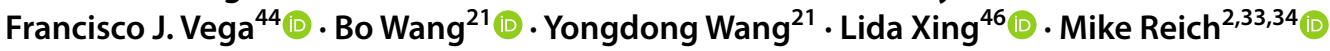

Received: 19 June 2020 / Accepted: 20 June 2020 / Published online: 8 August 2020

(c) The Author(s) 2020

\section{Motivation for this comment}

The Society of Vertebrate Paleontology (SVP) has recently circulated a letter, dated 21st April, 2020, to more than 300 palaeontological journals, signed by the President, Vice President and a former President of the society (Rayfield et al. 2020). In this letter, significant changes to the common practices in palaeontology are requested. In our present, multi-authored comment, we aim to demonstrate why these suggestions will not lead to improvement of both practice and ethics of palaeontological research, but conversely, will hamper its development. Despite our disagreement with the contents of the SVP letter, we appreciate the initiative and the opportunity to discuss scientific practices and the underlying ethics. Here, we consider different aspects of the suggestions of the SVP in which we see weaknesses and dangers. Our aim was to collect views from many different fields. The scientific world is, and should be, a pluralistic endeavour. This contribution deals with the aspects

Handling Editor: Tanja R. Stegemann.

Carolin Haug

carolin.haug@palaeo-evo-devo.info

Mike Reich

reich@snsb.de

Extended author information available on the last page of the article concerning amateur palaeontologists/citizen scientists/private collectors. Reference is made to Haug et al. (2020a) for another comment on aspects concerning Myanmar amber.

First of all, we reject the notion implied by the SVP letter that studying and describing specimens from private collections represent an unethical behaviour. The question whether privately owned specimens should be considered in scientific studies is a purely scientific question (as long as the specimens were legally obtained by their owner), and thus should be answered on the basis of the scientific problems and merits of such actions.

\section{Amateur palaeontologists/citizen scientists/ private collectors}

The statements in the letter of the Society of Vertebrate Paleontology (SVP) in our view shed a rather negative light on amateur palaeontologists/private collectors/citizen scientists, especially by noting that "fossils outside of the public domain, such as those in private collections and privately-operated for-profit museums that are not managed within the public trust as permanent institutions, do not meet [...] essential standards" (Rayfield et al. 2020: p. 2).

In our opinion, this statement is highly problematic. Amateur palaeontologists, or more generally, amateur scientists, contribute to science in an essential way augmenting 


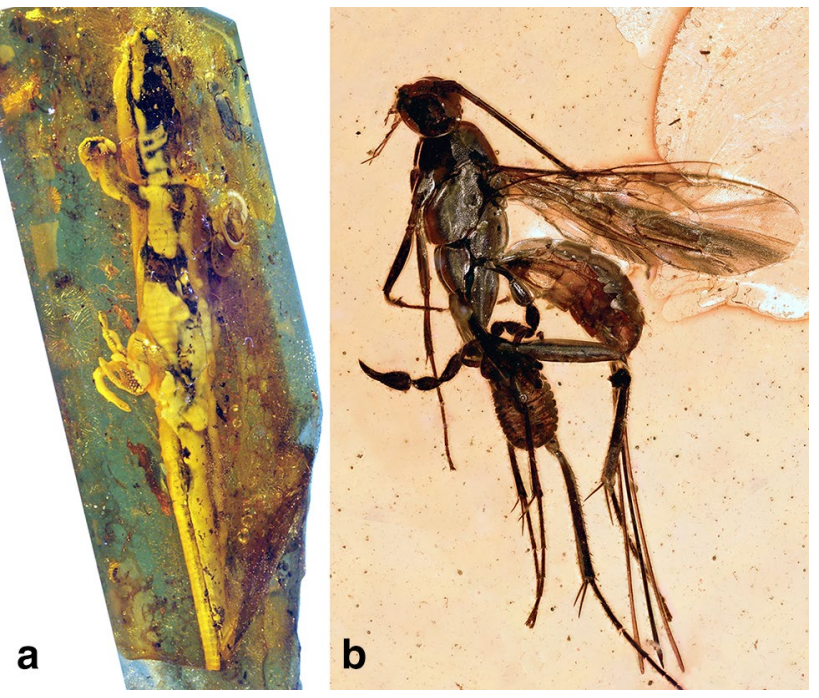

Fig. 1 Numerous unique fossil specimens and type material were at the time of the first scientific description in private ownership and came only into public collections after the death of the private collectors. a The iconic 'Königsberg amber lizard' Succinilacerta succinea (Boulenger, 1917) [specimen length $4.2 \mathrm{~cm}$ ] from the private amber collection of Richard Klebs (1850-1911). First described by George Albert Boulenger in 1917 and purchased by the Prussian State and the former Königsberg Albertus University in Königsberg in 1926; today, the holotype is deposited in the Göttingen Geoscience collections (GZG.BST.15000; see Reich 2008b). b This intriguing piece of Baltic amber with a male pseudoscorpion (Oligochernes bachofeni Beier, 1937) latched onto an ichneumonid wasp [specimens length $\sim 9.3 \mathrm{~mm}$ ] comes from the private collection of Adolf Freiherr Bachofen von Echt (1864-1946). It shows one of the first fossil examples of a phoretic relationship between pseudoscorpions and insects and was figured in numerous textbooks and other works. A large part of the Bachofen-Echt amber collection was purchased by the State of Bavaria in 1958, and the specimen is today part of the Munich Palaeontology collections (SNSB-BSPG 1958 VIII 195; see Reich and Wörheide 2018)

professionals. In palaeontology, they provide material (Fig. 1) and crucial information on many different groups, for example:

- Sharks: René Kindlimann, in Klug and Bolliger 2012; Mollen et al. 2012; Kriwet et al. 2015; Pollerspöck et al. 2018; Jambura et al. 2018, 2019; Bracher et al. 2019; Stumpf et al. 2019; Slater et al. 2020;

- Ray-finned fishes: Menzel et al. 1982 (see Lehmann 2003); Tischlinger and Arratia 2013; Ebert 2019;

- Plesiosaurs: Sachs et al. 2013;

- Mosasaurs: Mulder et al. 2013;

- Turtles, dinosaurs and dinosaur tracks: Ballerstedt 1921, 1922; Wiffen 1991; Lindgren et al. 2008 (see Hornung and Reich 2007); Rauhut et al. 2012; Field et al. 2020;

- Mammals: Micklich 2001; Martin et al. 2005; Mol et al. 2006; Reumer et al. 2018;

- Carboniferous vertebrates: Stan Wood, in Fraser et al. 2018; Smithson and Rolfe 2018;
- Echinoderms: Rievers 1961 (see Dehm 1961); Hess 1975; Kutscher 1978; Jagt 1999, 2000a, 2000b, 2000c, 2000d; Kutscher and Villier 2003 (see Reich 2001); Hess and Messing 2011 (see Etter 2018); Thuy et al. 2012, 2018; Jagt et al. 2014, 2018; Gale et al. 2018;

- Cephalopods: Mundlos 1973 (see Hagdorn 1988); Kaplan et al. 1987; Hewitt and Jagt 1999; Dietze and Hostettler 2016; Jagt and Jagt-Yazykova 2019; Jenny et al. 2019; Košták et al. 2019;

- Molluscs in general: Van Eldijk et al. 2019;

- Arachnids and myriapods: Bachofen-Echt 1934, 1942 (see Reich et al. 2019); Selden and Shear 1996; Bartel et al. 2015;

- Trilobites: Krueger 1972, 2004;

- Crustaceans: Bachmayer and Mundlos 1968; Hyžný and Hudáčková 2012; Van Bakel et al. 2012; Hyžný et al. 2014a, b; Audo et al. 2014, 2017; Haug et al. 2015; Fraaije et al. 2015, 2019; Nagler et al. 2016; Haug and Haug 2016a, 2017; Charbonnier et al. 2017; Keupp and Mahlow 2017; Charbonnier and Audo 2020; Joe Collins, in Donovan and Mellish 2020; Jakobsen et al. 2020; Pazinato et al. 2020;

- Insects: Kutscher 1999; Kutscher and Koteja 2000 (see Bechly and Wichard 2008; Reich 2008a; Dlussky and Rasnitsyn 2010); Hoffeins 2001; Hoffeins and Hoffeins 2003; Hörnig et al. 2014; Gröhn 2015; Van Eldijk et al. 2017; Haug et al. 2018, 2020b; Fowler 2019; Kirejtshuk 2020; Makarkin and Gröhn 2020;

- Sponges: Rhebergen and von Hacht 2000; Rhebergen and Botting 2014;

- General faunal assemblages: Ade 1989; Shabica and Hay 1997;

- Ferns: Reumer et al. 2020;

- Plants in general: Robert Noll, in Lausberg et al. 2003; Uhl et al. 2004; Rößler and Noll 2006, 2010; Kerp et al. 2007a, b; Knoll 2010; Rößler et al. 2012, 2014; Tavares et al. 2014; Neregato et al. 2015; Gröhn and Kobbert 2017; Van der Ham et al. 2017; Feng et al. 2019; Kelber 2019;

- Foraminiferans: Franke 1912, 1925, 1928 (see Schroeder 1991);

- Ichnofossils: Donovan et al. 2019.

The support of amateur or citizen scientists is particularly relevant in research fields in which there are either not sufficient numbers of professional scientists due to the decreasing number of palaeontologists in official institutions (museums, universities, geological surveys, etc.) in many countries or insufficient resources for conducting fieldwork or for obtaining scientifically important specimens. Different palaeontological societies even recognise outstanding achievements in palaeontology by amateurs with awards, e.g. the 'Harrell L. Strimple Award' of the Paleontological Society, the 'Mary Anning Award' of The Palaeontological Association, the 'Prix Saporta' of the Association Paléontologique 
Française, the 'Karl-Alfred-von-Zittel-Medaille' of the Paläontologische Gesellschaft, or the 'Amanz Gressly-Preis' of the Schweizerische Paläontologische Gesellschaft, just to name a few. An example from a field with important impact of amateur palaeontologists is palaeoentomology. Amateur palaeontologists and palaeoentomologists have always played an important role in the field of palaeoentomology; the discipline was largely founded by enthusiasts and collectors (Zherikhin et al. 2008; Szwedo and Sontag 2015; Beck and Joger 2018). The same is true for the study of fossil decapod crustaceans or fishes, which very often relies on the material collected by amateurs or are even described by them.

Citizen science programmes engaging the public in authentic research is widely championed for its potential to strengthen the understanding of the participants of science, environmental learning and critical thinking skills (Carlson and Fox 2012; Lynch et al. 2018). Amateur and citizen scientists are able to perform both long-term studies (at the same site, or a number of localities) and fossil rescue excavations (e.g. at construction sites or road works or when colliery tips are removed, e.g. see Austen 2001) as well as timeconsuming fossil-picking or fossil concentrations for which official institutions are often not able to provide time or financial resources. Thanks to amateur work under rules of the Portable Antiquities Scheme, nearly 1.5 million archaeological objects from UK were found, identified and databased (House of Lords 2006, https://finds.org.uk/). A recent, widely recognised example (e.g. by the BBC, Science, The Washington Post) comes from the field of insect ecology in which a massive decline of flying insect biomass over the last 27 years was documented with the aid of a team of amateur scientists (Hallmann et al. 2017, 2020). Another important example is the international "MECO Project" (Mediterranean Elasmobranch Citizen Observations), for which variable numbers of citizen scientists provide information for scientific studies (e.g. Jambura et al. in review). Since many years, a team of enthusiastic citizen scientists, guided by Angelika Leipner from the natural history department of the Museum am Schölerberg in Osnabrück (Germany), collects material in the well-known Piesberg quarry. A few years ago, they found a new lake deposit that has yielded several meso- and xerophyllous plants and an accompanying fauna that are normally not preserved in Pennsylvanian basinal coal-bearing strata. Important specimens have been deposited in the museum collection in Osnabrück, where palaeontologists have full access to the material. There is a steady exchange between collectors, museum curators and palaeontologists.

These are just a few of many examples in which amateur and citizen scientists contribute important work to scientific studies (see i.a. "Fossilfinder-Österreich forscht", "Citizen Science-myFossil", "Fossil Atmospheres
Project"; Fossilfinder 2020, myFossil 2020; FAP 2020). Joint knowledge, specimens and collections, efforts and activities of amateurs and institution-based professionals are more than the sum of their parts. Answers to diverse biological, environmental, and societal questions at the global scale, across eons of time, and spanning vast diversity across the Tree of Life is the main goal of the global community of museums (the 'Global Museum') joined together through emerging digital resources (Bakker et al. 2020). In many countries (e.g. Austria, Belgium, Czech Republic, Denmark, France, Germany, Italy, Lebanon, The Netherlands, Poland, Russia, Slovenia, Spain, Switzerland, UK; see Haug and Haug 2016b; Ouden and Pouwer 2018; Rauhut 2018; Furrer 2019; Fossiel.net Team 2020; ÖPG 2020; PalGes 2020), including the USA (MacFadden et al. 2016), the role of amateur palaeontologists in science has historically grown over many decades, to the point that it has proven crucial for advancing scientific knowledge, not least due to the declining number of professional palaeontologists employed by universities or public museums. In addition, it should not be forgotten that numerous former private collections form the basis of important palaeontological museums in Germany (Fig. 2), such as in Berlin (collection of Ernst Friedrich von Schlotheim; see Dietrich 1960, Hoppe 2001), Frankfurt/M. (collections of Johann Christian Senckenberg and Eduard Rüppell; see Struve 1967), and Munich (collection of Count Georg zu Münster; see Reich and Wörheide 2018).

We have to acknowledge the following realities:

1. It will always be impossible for professional palaeontologists to regularly survey all outcrops to secure all potentially important specimens.

2. It will never be possible to save all fossils and store them securely. This applies to plants, vertebrates, non-vertebrates and other organismic remains.

3. Potentially scientifically important specimens are lost every day, be it by erosion, by construction or quarry works.

4. The number of employed palaeontologists will never reach a level where all fossil groups can be described appropriately.

This being said, amateur or citizen palaeontologists do fill some of these gaps and it is beneficial for palaeontology to let them continue doing so:

1. They regularly survey fossiliferous outcrops.

2. They provide storage space for fossils (temporary or permanent).

3. They rescue many fossils from erosion or other destruction. 
4. Upon tolerant and open-minded behaviour of professional palaeontologists, they often happily inform about their discoveries and in many cases make them available to science.

The cases where the material gets destroyed, is stored without important information, or where the citizen palaeontologists keep their discoveries secret are likely almost negligible compared to those where our science actually profits from their activities. Mary Anning is possibly one of the most shining examples supporting this point. By contrast, the SVP letter will most likely have a negative impact on collaborations with amateur or citizen palaeontologists, as they might feel offended by its statements and be disinclined to cooperate in the future; additionally, it might put off young people just discovering palaeontology via amateur collecting (see also Liston 2016 on the symposium "Fossillegal" on ethics in palaeontology at the annual meeting of the European Association of Vertebrate Palaeontologists (EAVP) in 2016). We also would like to note that many (or most) professional palaeontologists have started as amateur palaeontologists, usually during their childhood; hence, the SVP letter potentially reduces the number of future professional palaeontologists. It actually unintentionally patronises this peer group, which is important for our field.

\section{Availability of specimens}

The SVP letter recommends that editors should add the following to their policies: "Any fossil specimen that is described or illustrated in a manuscript intended for publication must be formally accessioned into a permanent, accessible repository, where the specimen will be available for study by the scientific community. Long-term loans from private individuals or private organisations to repositories
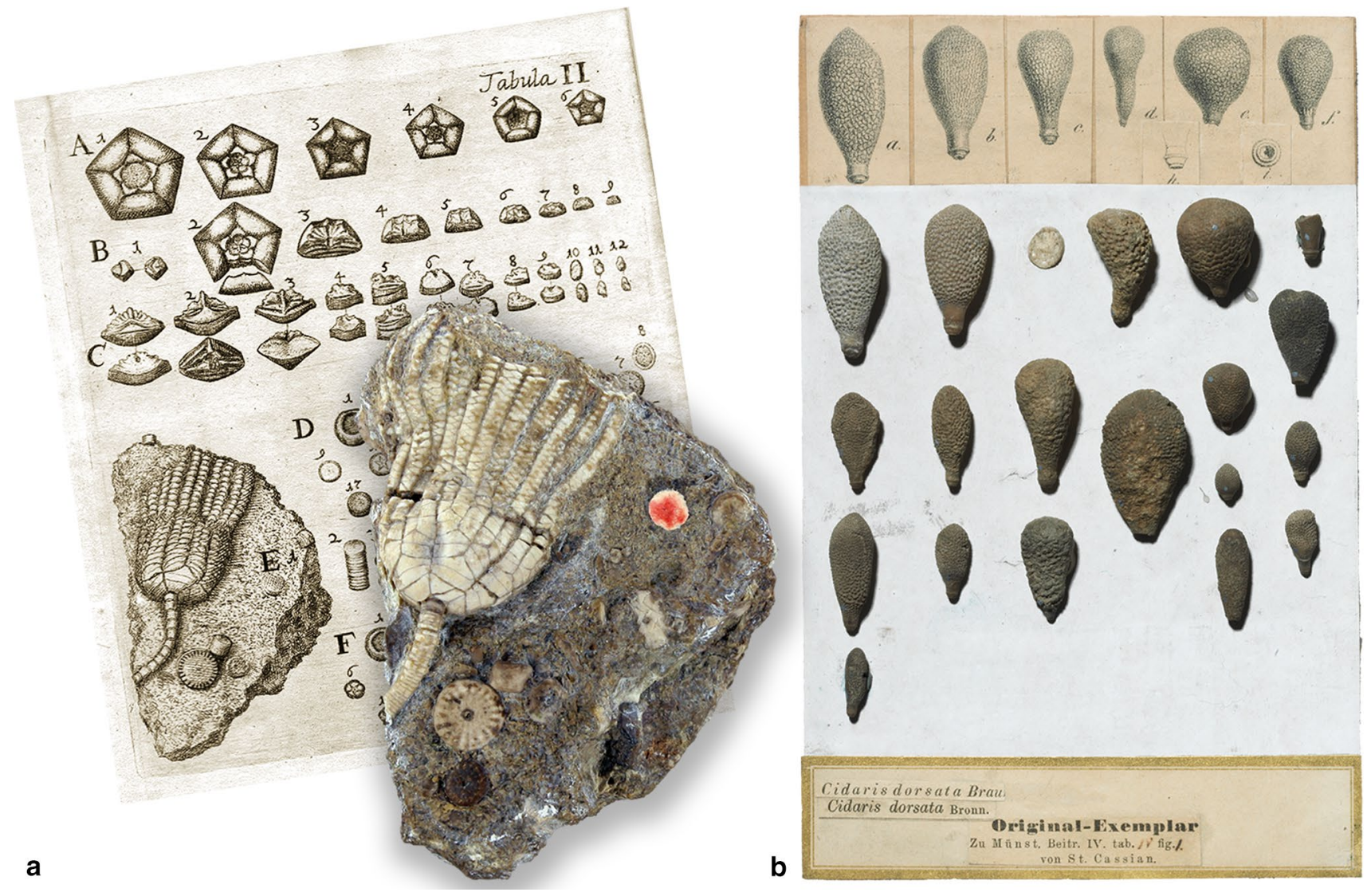

Fig. 2 Historically, numerous private collections form the basis of the palaeontology collections of our larger natural history museums - for example, in Berlin and Munich: a The holotype (MB.E 85) of the German 'Muschelkalk' crinoid Chelocrinus schlotheimi (Quenstedt, 1835) [specimen length $5.5 \mathrm{~cm}$ ] from the former private collection of Ernst Friedrich von Schlotheim (1764-1832) at the Berlin Naturkundemuseum was first part of other older private collections (Michael Reinhold Rosinus in Hann. Münden, 1687-1725;
Johann Heinrich Grätzel in Göttingen 1691-1770), but is one of the oldest specimens in the Berlin collections. b Echinoid spines from the classic Triassic Cassian beds of the Dolomites [paperboard width $12 \mathrm{~cm}$ ] were part of the former famous private collection of Count Georg zu Münster (1776-1844), which provided the historical basis for the foundation of the Munich Palaeontology museum (SNSB-BSPG AS o. Nr.; see Reich and Wörheide 2018) 
generally are not sufficient to ensure long-term access to fossils or reproducibility of results" (Rayfield et al. 2020: p. 2). This shows general concerns over the availability of specimens held in private collections and is indeed an important issue on which all authors agree. The deposition of a specimen in a publicly accessible collection is, of course, seen as the ideal scenario, but it should be noted that private collectors are in most cases willing either to donate their specimens to such institutions or sell them to institutions at a price often far below the market level. In Denmark, the national government has introduced a special scheme, by the name of 'Danekræ', which urges amateur collectors (even foreigners, see Hald 1993), to submit their palaeontological finds to a special committee to be evaluated (see Jakobsen 1991; Bonde et al. 2008). If deemed important as national heritage, the specimens are then bought from the collectors and placed in a public collection. In the Netherlands, museums that hold the so-called ANBI status, can buy (parts of) properly registered collections from private collectors, after obtaining assessment reports by external experts, by offering these collectors tax deductions for a period of 5 or 10 years.

Other solutions are also possible, for example, official recognition (via registration) of a scientifically very important specimen. The specimen itself can then stay in a private collection but still remains available to science. An example of such a registered find is the Altmühl (11th) specimen of the famous fossil bird Archaeopteryx (Foth et al. 2014), which is registered as no. 07901 in the "Datenbank geschützter Kulturgüter” after $\S 6$ Absatz 1 Nr. 2-4 KGSG (Kulturgutschutzgesetz). The same procedure was performed with the Schamhaupten (12th) specimen of Archaeopteryx (DNWK 02924; Rauhut et al. 2018) and the single specimen of the theropod dinosaur Sciurumimus albersdoerferi (DNWK 02922; Rauhut et al. 2012) (Fig. 3).

Even if none of the above options can be implemented, we consider it to be more problematic for science to ignore fossils deliberately just because they are not stored in a publicly accessible collection managed within the public trust than to include them in analyses, despite the fact that their final repository cannot be secured at that particular moment (e.g. Rauhut et al. 2014; Rauhut 2018). Not everything can be stored in a publicly accessible collection, e.g. many ichnofossils of larger vertebrates (tracks and trackways) of which normally casts are made or photogrammetry (structure from motion) is undertaken; the fossils themselves are left to erosion or mining (see also recent discussion in Lucas and Harris 2020). Additionally, there are several types of data in different fields of the natural sciences related to palaeontology that can generally not be deposited in museum collections:

Behavioural data: data acquired in behavioural studies are generally recorded as ethograms. Neither the observed specimens nor parts thereof are usually deposited.
Biomonitoring data: organisms captured for biomonitoring studies are in many cases not stored long-term. Specimens killed, for example, in traps or by fogging are counted and studied systematically, but afterwards disposed of. Organisms captured and measured alive are released again. It is a moot point whether deadly viruses should be retained following eradication in the population.

Destructive/invasive methods: for several types of analyses, the specimen analysed is destroyed or transformed during the analysis. A prominent example of such analyses is the serial sectioning of fossils (e.g. studies of Erik Jarvik on the sarcopterygian Eusthenopteron foordi; e.g. Jarvik 1942, 1954) or serial grinding to reconstruct their three-dimensional appearance if no other imaging methods are possible (e.g. fossils from the Herefordshire Lagerstätte: Siveter et al. 2020; rudist bivalves or cephalopods to see internal structures: Pascual-Cebrian et al. 2013; Tajika et al. 2020). Such a destruction or highly invasive treatment of fossils is widely accepted in the community, the only remaining data being images. This leads to the paradoxical situation: we accept that, following photography, a fossil could be systematically destroyed and still be published, but could not be stored in a private collection according to the requirement in the SVP letter.

If a specimen cannot be secured for further research, at least proper documentation through 2D/3D photographs, $\mathrm{X}$-ray computed tomography scans or other imaging methods will rescue data that can be used by scientists, regardless of the fact that the specimen involved is kept in a private collection with limited or no access or is destroyed. This is very similar to the increasing attitude of museums not providing real specimens on loan anymore, but instead providing virtual specimens for study, which can then be investigated by researchers worldwide without visiting the collections physically. As a consequence, the database involves not just the fossil specimens themselves, but also all images or other forms of data recorded from them, in contrast to the statement in the SVP letter (Rayfield et al. 2020: p. 2).

The International Code of Zoological Nomenclature (which also applies to fossils) does not require that the type specimen is deposited for the formal erection of species (ICZN 1999, Article 72.5.6; 73.1.4). This rule has specifically been added for not endangering rare extant species, but may well be expanded to include also rare fossils. The International Code of Nomenclature for algae, fungi, and plants strongly recommends that holotypes are deposited in a public collection; however, this is no formal requirement for a species erection (Turland et al. 2018, Recommendation 7A.1). The SVP letter does not cite the ICZN, which states that types "are to be held in trust for science by the persons 

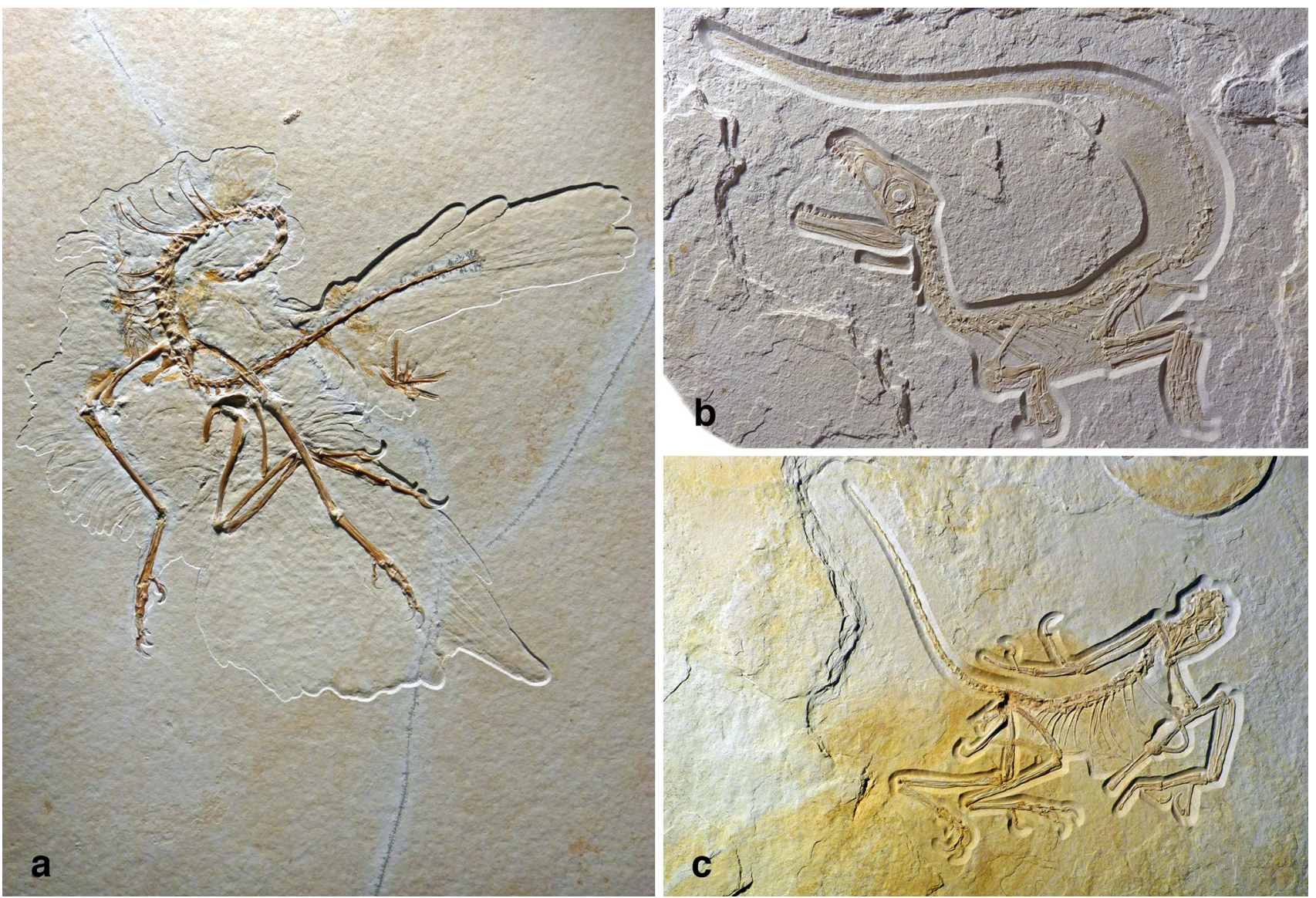

Fig. 3 Several unique and scientifically very important fossils still remain in private collections, but were officially registered in the 'Datenbank geschützter Kulturgüter' (database of protected cultural property) in Germany-for example, several iconic vertebrate fossils from the Upper Jurassic Plattenkalk deposits of Bavaria:

responsible for their safe keeping" (ICZN 2000, Article 72.10). The demand of the SVP letter to deposit fossils in a "stable repository within the public trust" begs the question what requirements such repositories should have. Many private collections or museums are well curated, well sorted and accessible to researchers (some prominent examples: the collection of Dr. Gordon Hubbell, Florida, one of the largest collections of fossil sharks and rays in the world, see Perez et al. 2020; the enormous collection of Baltic amber inclusions of Christel and Hans-Werner Hoffeins, Hamburg, which has been a major engine for our improved understanding of the Eocene fauna and climate, see von Tschirnhaus and Hoffeins 2009; the Sauriermuseum Aathal in Switzerland founded by Hans-Jakob Siber, see Siber and Möckli 2009; the Oertijdmuseum Boxtel in the Netherlands founded by the Fraaije family; the Urweltmuseum Hauff in Holzmaden, Germany, founded in 1936, see Lindgren et al. 2018, Jenny et al. 2019). This is not necessarily true of many public repositories, which are indeed "managed a, c The 11th (a) and 12th (c) skeletal specimens of the 'Urvogel' Archaeopteryx (from Eichstätt and Schamhaupten, respectively) [slab widths $\sim 37$ and $40 \mathrm{~cm}$ ]. b The juvenile specimen of the theropod dinosaur Sciurumimus albersdoerferi from Painten [slab width $\sim 40 \mathrm{~cm}$ ]

within the public trust". In Germany, Austria and probably in many other countries, university collections, which also hold type material, are uncurated, endangered or already lost because resources (curators, space) were reallocated in the course of current abandonment of specimen-based research in academia. Due to severe shortage of staff (and sometimes adequate storage facilities), appropriate curation is often not guaranteed. Many specimens are, in fact, lost to research, either because they cannot be found anymore, are inaccessible in an overcrowded store, were lost/destroyed (e.g. in different European museums in WWII, or during or in the aftermath of many modern wars such as those in Iraq, Afghanistan or Syria; in the worst case, almost the entire collection is lost as during the fire in the Museu Nacional da Universidade Federal do Rio de Janeiro in 2018), have degraded from neglect, or are contained in displays inaccessible for scientific investigation.

In some cases, the deposition of specimens in public collections was detrimental as the specimens were sold off 
subsequently at fossil fairs by the institution concerned. In the case of the San Diego Natural History Museum, which wanted to sell several historical specimens of the Sternberg collection in an auction in 2013, the protests of many colleagues led the museum to withdraw the specimens from the auction (Switek 2013). Another example is the large collection of the well-known French palaeobotanist Charles René Zeiller (1847-1915), former president of the Societé botanique de France and the Societé géologique de France, which was originally kept in the École Nationale Supérieure des Mines de Paris. This collection contained many type specimens, but in the 1980s, the host institute was no longer interested and it was moved to the University of Lyon-Villeurbanne. However, it soon appeared that important type specimens were missing. Rumour has it that they were sold at a fair soon after Zeiller passed away. Unfortunately, the situation in the new host institute was not ideal. In the mid1990s, several specimens appeared to be broken and parts of the same specimens were kept in different cabinets, partly even under different locality designations. The material was not labelled properly and holotypes were not marked. The new host institute did not have the humanpower and expertise to maintain this collection; it even did not have copies of the monographs in which the material was described. Without the material then kept in private collections, it would not have been possible to correlate a common type of Early Permian foliage with a specific fructification and to assign the reconstructed plant to the group Peltaspermales (Kerp 1982, 1988). Meanwhile, it is generally accepted that this group, which was traditionally regarded as typically Mesozoic, was much more common in the upper Palaeozoic. An inventory of the Rotliegend floras from the Saar-Nahe Basin (Kerp and Fichter 1985) would have been impossible without the help of many private collectors, e.g. Arnulf and Harald Stapf from Nierstein (Germany). Therefore, we vehemently disagree that the deposition of a specimen in a public collection automatically secures its availability for future research and that specimens in private collections are generally deemed inaccessible.

Another query concerning these issues comes to mind: What are the requirements for a "stable repository within the public trust" as requested in the SVP letter? Does it have to be funded by governmental institutions (in full, or partially), or may it also be privately financed? Can it be a regional/municipal museum funded by a province, a city or a smaller community? In general, the ICOM Code of Ethics for Museums (ICOM 2017) and the ICOM Code of Ethics for Natural History Museums (ICOM 2013) do not distinguish between museums in public/governmental and private properties. As long as a museum accepts and complies with the ICOM Code of Ethics, any private museum including private collections is de facto regarded as a stable, permanent and accessible repository for published fossil material.
To provide some numbers: in Bavaria, there are more than 1300 museums and officially recognised collections (also including art-historical, ethnological and other collections with some palaeontological specimens) in total. More than 1200 of these institutions are entirely not or not exclusively owned by the state (so-called "nichtstaatliche Museen"; Landesstelle für die nichtstaatlichen Museen in Bayern 2020). Hence, the vast majority of the collections are not (or not exclusively) under the control of the Bavarian state. This also applies to a larger part of all museums and institutions with palaeontological collections (>200) in Germany (cf. Jansen and Steininger 2002). Furthermore, several large museums like the American Museum of Natural History in New York or the Field Museum in Chicago are not in state hands, but are owned by private trusts. Another example is the Museo Paleontológico Egidio Feruglio in Trelew, Argentina. The museum was founded by a private foundation in collaboration with the city of Trelew, and has now become a research institution recognised by CONICET (Consejo Nacional de Investigaciones Científicas y Tecnícas) and the official fossil repository of the province of Chubut. In the USA and UK, an increasing number of art galleries are completely privately run (see Ellis 2008; Brown 2017), as are also several palaeontological museums (e.g. Wyoming Dinosaur Museum). There is an administrative continuum between fully state-owned and -managed institutions and entirely private institutions, with a large "grey area" with many intermediate states including growing mixed funding, in which private donors are playing significant roles.

Also, is it necessary to have an accreditation for such repositories? If yes, which organisation should take care of that? It becomes clear that it is not trivial to decide which types of repositories fall into the category "stable repository within the public trust". It depends on local circumstances and procedures, if any. It will remain impossible in many respects to store all the materials of these-in the broadest sense-private museums in state-controlled institutions. By contrast, the diversity of ownerships and funding bodies actually increases the likelihood that, in the long run, at least some of these collections survive, taking the volatility of politics and economies into account.

\section{Fewer restrictions may lead to better collaboration between professional and amateur palaeontologists: the Netherlands as an example}

Unlike archaeological remains that are protected by the Valletta Treaty (also known as the Malta Convention), and living biota (fauna, flora and habitats), which is protected by national and European legislation, fossil remains are not legally protected in the Netherlands. It is not forbidden to 
collect them or to possess them as a private person. The result of this situation is a relatively large number of private collectors. The vast majority of them is happily collaborating with scientists at universities and natural history museums. Quite a few 'amateurs' are engaged as voluntary curators. When new taxa are being described, the type specimens that they collected and kept in their possession are transferred to public collections, but most of the other material remains in their care. Often the collectors have made testaments regulating the eventual transfer of their collection to a museum after their death. Museums can make various legal arrangements to facilitate such bequests in advance.

Four major sources of fossil material attract special interest from private collectors: (1) glacial erratics ('geschiebe') originating from the Scandinavian/Baltic region (material dating from the Ordovician to the Cretaceous); (2) the Middle Triassic of the Winterswijk quarry (Muschelkalk, Anisian, c. $247 \mathrm{Ma}$ ); (3) the Late Cretaceous of the type Maastrichtian near Maastricht (c. 70-66 Ma); and (4) Cenozoic vertebrates from the North Sea Basin (some Miocene, and mostly Pleistocene; Fig. 4). Some examples are here given:

Ad (1). The find in a sand quarry near the German border of a small enigmatic fossil by an amateur collector that was donated to the museum Natura Docet/Wonderryck Twente (NDWT, Denekamp) led to the discovery of about a dozen similar fossils from a discrete area spanning the Dutch-German border in several private collections. The fossils were identified as leaf imprints of an Early Jurassic fern (Clathropteris meniscioides) originating from source sediments in southern Sweden, and transported to the Netherlands by the Eridanos river system (Reumer et al. 2020). Some, but not all, of the specimens will be donated to NDWT or to the University Museum in Bremen, Germany. These specimens of Clathropteris were the first ever discovered in the Netherlands, and the help of amateur collectors was indispensable in tracking them.

Ad (2). A micritic limestone of Anisian age has been commercially quarried in an open pit mine near Winterswijk, eastern Netherlands, since the 1930s. An amateur discovered fossil bones of marine reptiles and ichnofossils (foot prints) during the 1960s, and ever since a flourishing group of amateur collectors has been actively searching for fossils. Many of them have amassed important collections. So far, three ichnofossil taxa, five marine reptile species, three crustaceans and one fish species have been discovered that were new to science, and subsequently described. The type specimens of these were donated to public repositories. Some recent examples are the skull of Nothosaurus winkelhorsti (named after the amateur collector Herman Winkelhorst; Klein and Albers 2009), Palatodonta bleekeri (named after the amateur collector Remco Bleeker; Neenan et al. 2013), Pararcus diepenbroeki (named after the amateur collector Gerben Diepenbroek; Klein and
Scheyer 2014), and the cyclid crustacean Halicyne oosterinkorum (named after the late collector Henk Oosterink and his family; Schweitzer et al. 2019). Recently, a new marine isopod species was found by Mr. Winkelhorst, donated from his collection to the Naturalis Biodiversity Center, and described as the new taxon Gelrincola winterswijkensis (Schädel et al. 2020). It can be stated without exaggeration that most of our knowledge about the Middle Triassic of the western Germanic Basin is based on material collected by amateurs. They wholeheartedly made and make their collections available for study to scientists from the universities in Bonn (Germany) and Utrecht (The Netherlands), and Naturalis Biodiversity Center (Leiden, The Netherlands).

Ad (3). A private collector discovered a large mosasaur at the huge ENCI quarry near Maastricht, where Cretaceous limestone was excavated until two years ago. The specimen was taken to the Natural History Museum Maastricht, and turned out to be a new species of mosasaur. It was formally described as Prognathodon saturator in 2002 in an article with the finder as first author (Dortangs et al. 2002). Much of the material from the Maastrichtian is discovered, collected, prepared and studied by amateur collectors, without whom our knowledge of the type Maastrichtian would be much less detailed.

Ad (4). In the Netherlands, being situated on the edge of the North Sea Basin, many fossil vertebrates are being found in its mostly sandy sediments. Famous sources were traditionally the sand and gravel pits along the major rivers (Rhine and Meuse), the large estuaries in the southwestern province of Zeeland, and the bottom of the North Sea. Large sand supplements to the (eroding) coast and for constructing extensions of the Rotterdam Port (the so-called Maasvlakte 1 and Maasvlakte 2) are more recent sources of an abundance of fossil vertebrates, mostly (but not necessarily) originating from the Late Pleistocene fauna of the Mammoth Steppe. Nearly all fossils from the Maasvlakte and other localities were collected by amateurs and kept in their collections. Here again, most of these collections are made available for scientific research (e.g. the specimens of the Barbary monkey Macaca sylvanus, see Reumer et al. 2018; Fig. 4). A by now famous fossil, found on board a fishing vessel by a private collector and donated to the Natural History Museum in Rotterdam, is the (so far) only Late Pleistocene sabretooth cat Homotherium latidens (Reumer et al. 2003). Here again, our knowledge of the northwest European late Cenozoic largely depends on the effort and collections of citizen scientists.

To sum up, it can be noted that palaeontology in the Netherlands owes a great debt to the effort of amateur collectors and citizen scientists. Their collections are an indispensable source of material. The absence of legal protection for fossils makes it easy for them to collect, 


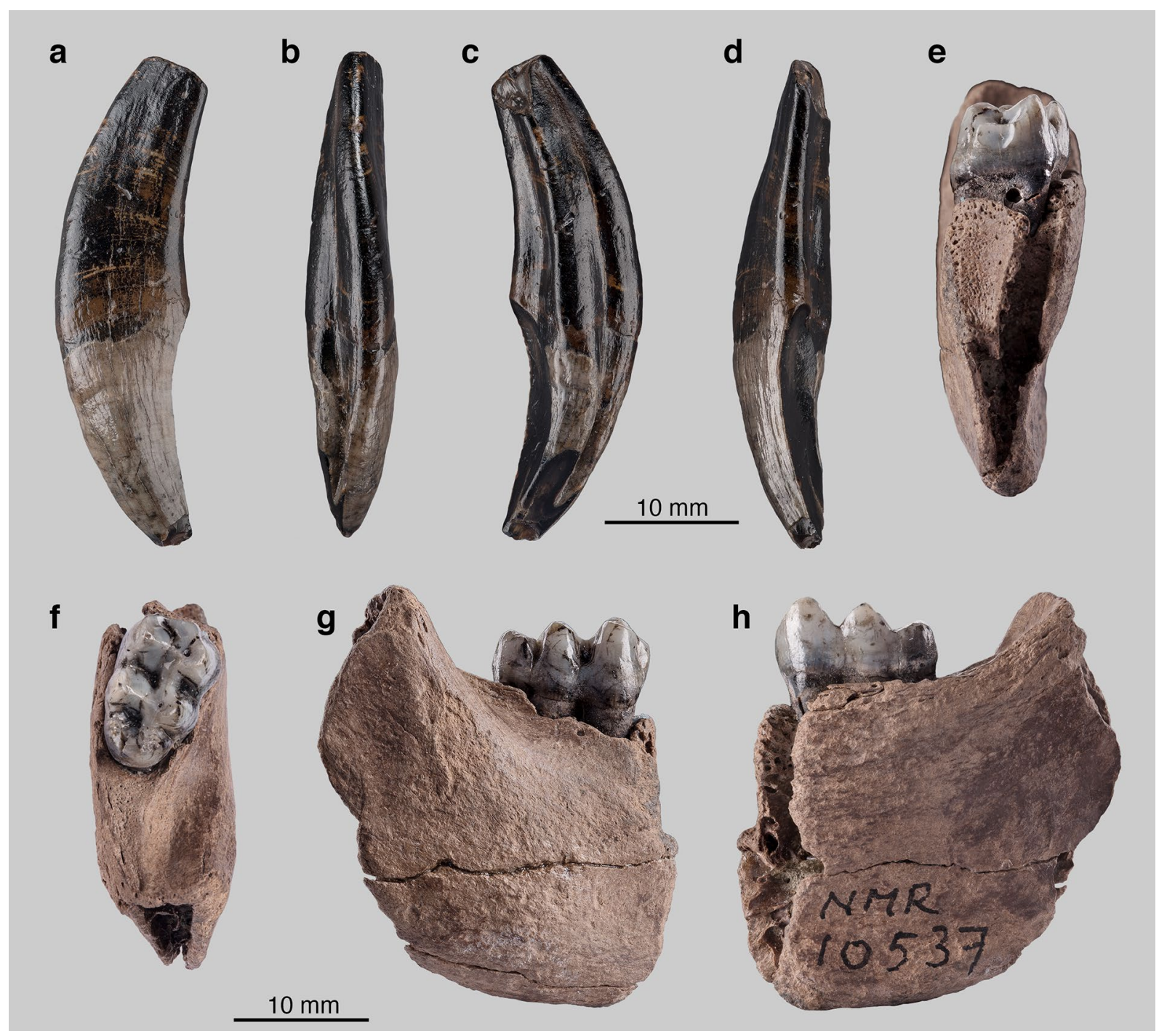

Fig. 4 The Netherlands is one example of a country with a strong tradition of fruitful collaborations between private collectors and professional palaeontologists, leading to important scientific discoveries such as specimens of the Barbary monkey Macaca sylvanus (Linnaeus, 1758) from Maasvlakte 2, Rotterdam, The Netherlands (Pleistocene; see Reumer et al. 2018). a-d Left upper canine tooth (C sup. sin.) found by and in the collection of Mr. Henk Houtgraaf, Papendrecht (The Netherlands), inv. nr. HHO-0420. a Buccal view.

prepare, share, and publish their material. We should also keep in mind that amateurs often have more time and sometimes even more money to pursue their avocation than do professional palaeontologists who are tied to responsibilities and budgets and ever decreasing storage capacity. b Anterior (mesial) view. c Lingual view. d Posterior (distal) view. e-h Right mandibular fragment with the lower third molar (M3 dex.) preserved, found by Mr. Cock van den Berg, collection of the Natural History Museum Rotterdam, inv. nr. 999100010537. e Anterior (mesial) view. f Occlusal view. g Buccal view. h Lingual view. Photographs were taken by Susann Döring and arranged by Evelin Haase (Senckenberg Research Station of Quaternary Palaeontology Weimar, Germany)

\section{Conclusions}

All in all, the situation is far more complex than presented in the SVP letter. Therefore, we recommend that the editors of palaeontological journals should postpone the implementation of the requested changes formulated in that particular letter because we believe that the issues raised in the letter should first lead to a discussion in the whole palaeontological community, including all its subdisciplines, with a worldwide participation before appropriate ethical standards 
for scientific journals are verbalized. Such a discussion is essential, because requests formulated by only one part of the palaeontological community, in a seemingly rushed manner, will have serious consequences for research far beyond their own particular subfield or their regional scientific community; indeed, it seems as if these consequences have apparently not been evaluated thoroughly by the authors of the SVP letter. If palaeontological practice is to be reformed, such reforms should be broadly supported and not unilaterally imposed. Moreover, the recommendations of the SVP would doubtlessly drive a valuable community of active amateur researchers/citizen scientists into isolation and eventually obliteration. Thereby, our research field would lose parts of its most important peer group, rich sources of material and data, as well as sources of young academics. Instead, we recommend fostering the diversity in our science on all levels, i.e. from gender via ethnical groups to modes of repository, material sources, and educational background of non-professional collaborators.

Acknowledgements Open Access funding provided by Projekt DEAL.

Open Access This article is licensed under a Creative Commons Attribution 4.0 International License, which permits use, sharing, adaptation, distribution and reproduction in any medium or format, as long as you give appropriate credit to the original author(s) and the source, provide a link to the Creative Commons licence, and indicate if changes were made. The images or other third party material in this article are included in the article's Creative Commons licence, unless indicated otherwise in a credit line to the material. If material is not included in the article's Creative Commons licence and your intended use is not permitted by statutory regulation or exceeds the permitted use, you will need to obtain permission directly from the copyright holder. To view a copy of this licence, visit http://creativecommons.org/licenses/by/4.0/.

\section{References}

Ade, J. 1989. Key to identify Pennsylvanian fossil animals of the Mazon Creek area. 1-125. Downers Grove, Ill.: ESCONI.

Audo, D., G. Schweigert, J.T. Haug, C. Haug, J.-P. Saint Martin, and S. Charbonnier. 2014. Diversity and palaeoecology of the enigmatic genus Knebelia (Eucrustacea, Decapoda, Eryonidae) from Upper Jurassic plattenkalks in southern Germany. Palaeontology 57(2): 397-416. https://doi.org/10.1111/pala.12071.

Audo, D., M. Williams, S. Charbonnier, and G. Schweigert. 2017. Gabaleryon, a new genus of widespread early Toarcian polychelidan lobsters. Journal of Systematic Palaeontology 15(3): 205-222. https://doi.org/10.1080/14772019.2016.1167786.

Austen, P.A. 2001. The Writhlington experience. In A future for fossils, eds. M.G. Bassett, A.H. King, J.G. Larwood, N.A. Parkinson, and V.K. Deisler), 67-70. Cardiff: National Museum of Wales. (=Geological Series, National Museum of Wales 19).

Bachmayer, F., and R. Mundlos. 1968. Die tertiären Krebse von Helmstedt bei Braunschweig, Deutschland. Annalen des Naturhistorischen Museums in Wien 72: 649-692.

Bachofen-Echt, A. 1934. Beobachtungen über im Bernstein vorkommende Spinnengewebe. Biologia Generalis 10(1): 179-184.
Bachofen-Echt, A. 1942. Über die Myriapoden des Bernsteins. Palaeobiologica 7(5/6): 394-403.

Bakel, B.W.M. van, D. Guinot, P. Artal, R.H.B. Fraaije, and J.W.M. Jagt. 2012. A revision of the Palaeocorystoidea and the phylogeny of raninoidian crabs (Crustacea, Decapoda, Brachyura, Podotremata). Zootaxa 3215: 1-216.

Bakker, F.T., A. Antonelli, J.A. Clarke, J.A. Cook, S.V. Edwards, P.G.P. Ericson, S. Faurby, N. Ferrand, M. Gelang, R.G. Gillespie, M. Irestedt, K. Lundin, E. Larsson, P. Matos-Maraví, J. Müller, T. von Proschwitz, G.K. Roderick, A. Schliep, N. Wahlberg, J. Wiedenhoeft, and M. Källersjö. 2020. The Global Museum: natural history collections and the future of evolutionary science and public education. PeerJ 8: e8225. https:// doi.org/10.7717/peerj.8225.

Ballerstedt, M. 1921. Dinosaurierfährten im Wealdensandstein des Harrl bei Bückeburg und eine zur Zeit freiliegende Spur eines „vierfüßigen“ plumpen Dinosauriers. Zeitschrift der Deutschen Geologischen Gesellschaft 72: 231-233.

Ballerstedt, M. 1922. Über das Plastron der Schildkröten des Keupers und die Gestalt der Panzerschale von Proganochelys quenstedtii Baur nach dem Tübinger Fossil. Paläontologische Zeitschrift 4(1): 64-74. https://doi.org/10.1007/BF03041559.

Bartel, C., M. Konikiewicz, J. Mąkol, A. Wohltmann, and J.A. Dunlop. 2015. Smaridid mites in Baltic and Bitterfeld amber, with notes on the fossil record of terrestrial Parasitengona (Trombidiformes: Prostigmata). Annales Zoologici 65: 641-659.

Bechly, G., and W. Wichard. 2008. Damselfly and dragonfly nymphs in Eocene Baltic amber (Insecta: Odonata), with aspects of their palaeobiology. Palaeodiversity 1: 37-73.

Beck, L.A., and U. Joger (eds.). 2018. Paleontological collections of Germany, Austria and Switzerland. The history of life of fossil organisms at museums and universities, xiii $+1-573$. Cham: Springer.

Beier, M. 1937. Pseudoscorpione aus dem baltischen Bernstein. In Festschrift zum 60. Geburtstage von Professor Dr. Embrik Strand, vol. II, 302-316. Riga: Izd. Latvija.

Bonde, N., S. Andersen, N. Hald, and S.L. Jakobsen. 2008. Danekrae: Danmarks bedste fossiler, 1-225. København: Gyldendals.

Boulenger, G. 1917. A revision of the lizards of the genus Nucras Gray. Annals of the South African Museum 13(6): 195-216.

Bracher, H., E. Unger, J. Jost, B. Lüdi, I. Feichtinger, and J. Pollerspöck, J. 2019. Haie und Rochen der Molasse, Assessed June 01, 2020 at https://molasse-haie-rochen.de.

Brown, K. 2017. Public vs private art collections: who controls our cultural heritage? The Conversation, August 11, 2017, Assessed June 01, 2020 at https://theconversation.com/publi c-vs-private-art-collections-who-controls-our-cultural-herit age-80594.

Carlson, J.C., and M.S. Fox. 2012. Citizen scientists in entomology research. American Entomologist 58(1): 8.

Charbonnier, S., and D. Audo. 2020. A new stenochirid lobster (Crustacea, Decapoda, Stenochiridae) from the Early Jurassic of France. Geodiversitas 42(7): 93-102.

Charbonnier, S., D. Audo, A. Garassino, and M. Hyžný. 2017. Fossil Crustacea of Lebanon. Mémoires du Muséum National d'Histoire Naturelle 210: 1-252.

Dehm, R. 1961. Über Pyrgocystis (Rhenopyrgus nov. subgen.) coronaeformis Rievers aus dem rheinischen Unter-Devon. Mitteilungen der Bayerischen Staatssammlung für Paläontologie und historische Geologie 1: 13-17.

Dietrich, W.O. 1960. Geschichte der Sammlungen des GeologischPaläontologischen Instituts und Museums der Humboldt-Universität zu Berlin. Berichte der geologischen Gesellschaft in der DDR 5(4): 247-289.

Dietze, V., and B. Hostettler. 2016. Occurrences of the ammonite genus Clydoniceras Blake, 1905 in the Middle Jurassic (Upper 
Bathonian, Discus Zone) of NW Switzerland. Proceedings of the Geologists' Association 127(2): 218-229. https://doi. org/10.1016/j.pgeola.2015.11.002.

Dlussky, G.M., and A.P. Rasnitsyn. 2010. Ants (Insecta: Vespida: Formicidae) in the upper Eocene amber of central and Eastern Europe. Paleontological Journal 43(9): 1024-1042.

Donovan, S.K., and C.J.T. Mellish. 2020. Mr. Joseph Stephen Henry (Joe) Collins, 1927-2019. Bulletin of the Mizunami Fossil Museum 46: 103-114.

Donovan, S.K., J.W.M. Jagt, and P.H.M. van Knippenberg. 2019. Clusters of shallow pits in gastropod shells from the type area of the Maastrichtian (Upper Cretaceous, the Netherlands). Bulletin of Geosciences 94: 425-430.

Dortangs, R.W., A.S. Schulp, E.W.A. Mulder, J.W.M. Jagt, H.H.G. Peeters, and D.T. de Graaf. 2002. A large new mosasaur from the Upper Cretaceous of The Netherlands. Netherlands Journal of Geosciences/Geologie en Mijnbouw 81(1): 1-8.

Ebert, M. 2019. Zandtfuro and Schernfeldfuro, new genera of Halecomorphi (Actinopterygii) from the Upper Jurassic Solnhofen archipelago. Journal of Vertebrate Paleontology 39(2): e1592759. https://doi.org/10.1080/02724634.2019.1592759.

Eldijk, T. van, G. Goris, A. Haarhuis, J. Lankamp, H. Winkelhorst, J.W.F. Reumer, A. Nel, and T. Wappler. 2017. New fossil insects from the Anisian (Lower to Middle Muschelkalk) from the Central European Basin (Germany and The Netherlands). PalZ. Paläontologische Zeitschrift 91(2): 185-194. https://doi. org/10.1007/s12542-017-0343-y.

Eldijk, T.J.B. van, R. Heerschop, A. Haarhuis, H. Winkelhorst, and A.A. Klompmaker. 2019. Non-arthropod invertebrates from the Middle Triassic of Winterswijk. Staringia 16: 185-190.

Ellis, A. 2008. The problem with privately funded museums. The Art Newspaper 17(188): 24. Assessed June 01, 2020 at https:// aeaconsulting.com/insights/the_problem_with_privately_funde d_museums.

Etter, W. 2018. Hans Hess (1930-2017): a life-long passion for echinoderms. In Special Issue: Hans Hess: A lifelong passion for fossil echinoderms, eds. C.A. Meyer, B. Thuy, C. Klug, D. Marty, and S.K. Donovan. Swiss Journal of Palaeontology 137: 127-131. https://doi.org/10.1007/s13358-017-0143-8.

FAP. 2020. Fossil atmospheres project [of the national museum of natural history and the smithsonian environmental research center], Accessed May 18, 2020 at https://www.si.edu/fossil-atmosphere s/leaf-survey.

Feng, Z., M. Bertling, R. Noll, A. Ślipiński, and R. Rößler. 2019. Beetle borings in wood with host response in early Permian conifers from Germany. PalZ. Paläontologische Zeitschrift 93(3): 409421. https://doi.org/10.1007/s12542-019-00476-9.

Field, D.J., J. Benito, A. Chen, J.W.M. Jagt, and D.T. Ksepka. 2020. Late Cretaceous neornithine from Europe illuminates the origins of crown birds. Nature 579(7799): 397-401. https://doi. org/10.1038/s41586-020-2096-0.

Fossiel.net Team. 2020. Locations, Accessed May 18, 2020 at https:// www.paleontica.org/sites/all_sites_overview.php.

Fossilfinder. 2020. Fossilfinder - Österreich forscht [of the Natural History Museum Vienna], Accessed May 18, 2020 at https:// www.citizen-science.at/projekte/fossilfinder.

Foth, C., H. Tischlinger, and O.W.M. Rauhut. 2014. New specimen of Archaeopteryx provides insights into the evolution of pennaceous feathers. Nature 511(7507): 79-82. https://doi.org/10.1038/natur e13467.

Fowler, M.J.F. 2019. Eocene world: Imaging fossil insects in Baltic amber. Bulletin of the Amateur Entomologists' Society 78: 139-146.

Fraaije, R.H.B., B.W.M. van Bakel, and J.W.M. Jagt. 2015. A new Albian hermit crab (Anomura, Paguroidea) from Franceanother example of capsulated setae in an extinct form. Neues
Jahrbuch für Geologie und Paläontologie, Abhandlungen 277(3): 353-359. https://doi.org/10.1127/njgpa/2015/0511.

Fraaije, R.H.B., B.W.M. van Bakel, J.W.M. Jagt, S. Charbonnier, and J.-P. Pezy. 2019. The oldest record of galatheoid anomurans (Decapoda, Crustacea) from Normandy, northwest France. Neues Jahrbuch für Geologie und Paläontologie, Abhandlungen 292(3): 291-297. https://doi.org/10.1127/njgpa/2019/0821.

Franke, A. 1912. Die Foraminiferen des Unter-Eocäntones der Ziegelei Schwarzenbeck. Jahrbuch der Königlich Preussischen geologischen Landesanstalt und Bergakademie zu Berlin 32(II): 106-111.

Franke, A. 1925. Die Foraminiferen des norddeutschen Unter-Oligocäns. In Festschrift zu der Feier des 50jährigen Bestehens des Museums für Natur- und Heimatkunde in Magdeburg, ed. A. Mertens. Abhandlungen und Berichte aus dem Museum für Natur- und Heimatkunde und den Naturwissenschaftlichen Verein (Magdeburg) 4(2): 146-190.

Franke, A. 1928. Die Foraminiferen der Oberen Kreide Nord- und Mitteldeutschlands. Abhandlungen der Preußischen geologischen Landesanstalt (Neue Folge) 111: 1-207.

Fraser, N.C., T.R. Smithson, and J.A. Clack. 2018. A legacy in fossils: a tribute to Stan Wood-Preface. Earth and Environmental Science Transactions of The Royal Society of Edinburgh 108(1): 1-5. https://doi.org/10.1017/S1755691018000191.

Furrer, H. 2019. Fische und Saurier aus dem Hochgebirge: Fossilien aus der mittleren Trias bei Davos. Neujahrsblatt der Naturforschenden Gesellschaft in Zürich NGZH 221: 1-112.

Gale, A.S., E. Sadorf, and J.W.M. Jagt. 2018. Roveacrinida (Crinoidea, Articulata) from the upper Maastrichtian Peedee Formation (upper Cretaceous) [sic] of North Carolina, USA-The last pelagic microcrinoids. Cretaceous Research 85: 176-192. https ://doi.org/10.1016/j.cretres.2018.008.

Gröhn, C. 2015. Einschlüsse im Baltischen Bernstein, 1-424. Kiel: Wachholtz Verlag/Murmann Publishers.

Gröhn, C., and M.J. Kobbert. 2017. Pflanzen in Bernstein. Seit der Saurierzeit eingeschlossen. 1-240. Kiel: Wachholtz Verlag/Murmann Publishers.

Hagdorn, H. 1988. Das Sammlerporträt: Dr. h.c. Rudolf Mundlos. Fossilien 5(4): 184-188.

Hald, N. 1993. Drei Jahre Danekræ-Ein Gesetz und was es bewirkt hat. Fossilien 10(6): 346-350.

Hallmann, C.A., M. Sorg, E. Jongejans, H. Siepel, N. Hofland, H. Schwan, W. Stenmans, A. Müller, H. Sumser, T. Hörren, D. Goulson, and H. de Kroon. 2017. More than 75 percent decline over 27 years in total flying insect biomass in protected areas. PLOS ONE 12(10): e0185809. https://doi.org/10.1371/journ al.pone.0185809.

Hallmann, C.A., T. Zeegers, R. van Klink, R. Vermeulen, P. van Wielink, H. Spijkers, J. van Deijk, W. van Steenis, and E. Jongejands. 2020. Declining abundance of beetles, moths and caddisflies in the Netherlands. Insect Conservation and Diversity 13(2): 127139. https://doi.org/10.1111/icad.12377.

Ham, R.W.J.M. van der, J.H.A. van Konijnenburg-van Cittert, J.W.M. Jagt, L. Indeherberge, R. Meuris, M.J.M. Deckers, R. Renkens, and J. Laffineur. 2017. Seagrass stems with attached roots from the type area of the Maastrichtian Stage (NE Belgium; SE Netherlands): morphology, anatomy, and ecological aspects. Review of Palaeobotany and Palynology 241: 49-69.

Haug, C., and J.T. Haug. 2016a. Über die Zusammenarbeit von Hobbypaläontologen und Wissenschaftlern. Der Steinkern 24: 90-93.

Haug, J.T., and C. Haug. 2016b. "Intermetamorphic" developmental stages in 150 million-year-old achelatan lobsters-the case of the species tenera Oppel, 1862. Arthropod Structure and Development 45: 108-121. https://doi.org/10.1016/j.asd.2015.10.001.

Haug, J.T., and C. Haug. 2017. A new glimpse on Mesozoic zooplankton-150 million-year-old lobster larvae. PeerJ 5: e2966. https ://doi.org/10.7717/peerj.2966. 
Haug, J.T., P. Müller, and C. Haug. 2018. The ride of the parasite: a 100-million-year old mantis lacewing larva captured while mounting its spider host. Zoological Letters 4: 31. https://doi. org/10.1186/s40851-018-0116-9.

Haug, J.T., J.W. Martin, and C. Haug. 2015. A 150-million-year-old crab larva and its implications for the early rise of brachyuran crabs. Nature Communications 6: 6417. https://doi.org/10.1038/ ncomms7417.

Haug, J.T., D. Azar, A. Ross, J. Szwedo, Bo Wang, A. Arillo, V. Baranov, J. Bechteler, R. Beutel, V. Blagoderov, X. Delclòs, J. Dunlop, K. Feldberg, R. Feldmann, C. Foth, R.H.B. Fraaije, A. Gehler, D. Harms, L. Hedenäs, M. Hyžny, J.W.M. Jagt, E.A. Jagt-Yazykova, E. Jarzembowski, H. Kerp, P.K. Khine, A.G. Kirejtshuk, C. Klug, D.S. Kopylov, U. Kotthoff, J. Kriwet, R.C. McKellar, A. Nel, C. Neumann, A. Nützel, E. Peñalver, V. Perrichot, A. Pint, E. Ragazzi, L. Regalado, M. Reich, J. Rikkinen, E.-M. Sadowski, A.R. Schmidt, H. Schneider, F.R. Schram, G. Schweigert, P. Selden, L.J. Seyfullah, M.M. Solórzano-Kraemer, J.D. Stilwell, B.W.M. van Bakel, F.J. Vega, Yongdong Wang, Lida Xing, and Carolin Haug. 2020a. Comment on the letter of the Society of Vertebrate Paleontology (SVP) dated April 21, 2020 regarding "Fossils from conflict zones and reproducibility of fossil-based scientific data": Myanmar amber. PalZ. Paläontologische Zeitschrift 94(3). https ://doi.org/10.1007/s12542/s12542-019-00503-9

Haug, J.T., M. Schädel, V.A. Baranov, and C. Haug. 2020. An unusual 100-million-year old holometabolan larva with a piercing mouth cone. PeerJ 8: e8661. https://doi.org/10.7717/peerj.8661.

Hess, H. 1975. Die fossilen Echinodermen des Schweizer Juras. Veröffentlichungen aus dem Naturhistorischen Museum Basel 8: $1-130$.

Hess, H., and C.G. Messing. 2011. Treatise on Invertebrate Paleontology, Pt. T, Echinodermata 2 (revised): Crinoidea, Subclass Articulata, vol. 3. 1-290. Lawrence, Kans.: Kansas University Paleontological Institute.

Hewitt, R.A., and J.W.M. Jagt. 1999. Maastrichtian ceratisepia and mesozoic cuttlebone homeomorphs. Acta Palaeontologica Polonica 44: 305-326.

Hörnig, M.K., C. Haug, K.J. Herd, and J.T. Haug. 2014. New insights into dictyopteran early development: smallest Palaeozoic roachoid nymph found so far. Palaeodiversity 7: 159-165.

Hoffeins, H.W. 2001. On the preparation and conservation of amber inclusions in artificial resin. Polskie Pismo Entomologiczne 70: 215-219.

Hoffeins, C., and H.W. Hoffeins. 2003. Untersuchungen über die Häufigkeit von Inklusen in Baltischem und Bitterfelder Bernstein (Tertiär, Eozän) aus unselektierten Aufsammlungen unter besonderer Berücksichtigung der Ordnung Diptera. Studia dipterologica 10(2): 381-392.

Hoppe, G. 2001. Zur Geschichte der Geowissenschaften im Museum für Naturkunde zu Berlin. Teil 4: Das Mineralogische Museum der Universität Berlin unter Christian Samuel Weiss von 1810 bis 1856. Mitteilungen aus dem Museum für Naturkunde der Humboldt-Universität in Berlin (Geowissenschaftliche Reihe) 4: 3-27.

Hornung, J.J., and M. Reich. 2007. Krokodile, Schildkröten and Dinosaurier. Die "Wealden"-Sammlung der Universität Göttingen. Fossilien 24(1): 32-36.

House of Lords. 2006. House of lords, science and technology committee. 9th report of session 2005-06. Science and heritage. Report with evidence. House Lords Paper 256: 1-287.

Hyžný, M., and N. Hudáčková. 2012. Redescription of two ghost shrimps (Decapoda: Axiidea: Callianassidae) from the Middle Miocene of the Central Paratethys: systematics, intraspecific variation, and in situ preservation. Zootaxa 3210: 1-25.

Hyžný, M., B.W.M. van Bakel, and D. Guinot. 2014a. Etisus evamuellerae, a new xanthid crab (Decapoda, Brachyura) from the Middle Miocene of Austria and Hungary. In Proceedings of the 5th Symposium on Mesozoicc and Cenozoic Decapod Crustaceans, Krakow, Poland, 2013: A tribute to Pál Mihály Müller, eds. R.H.B. Fraaije, M. Hyžný, J.W.M. Jagt, M. Krobicki, and B.W.M. van Bakel. Scripta Geologica 147: 221-231.

Hyžný, M., I. Hoch, F.R. Schram, and S. Rybár. 2014b. Crangopsis Salter, 1863 from the Lower Carboniferous (Mississippian) of the Ostrava Formation-the first record of Aeschronectida (Malacostraca: Hoplocarida) from continental Europe. Bulletin of Geosciences 89(4): 707-717.

ICOM. 2013. Code of Ethics for Natural History Museums. Paris: International Council of Museums (ICOM). Accessed June 12, 2020 at https://icom.museum/en/resources/standards-guidelines /code-of-ethics/.

ICOM. 2017. Code of Ethics for Museums. Paris: International Council of Museums (ICOM). Accessed June 12, 2020 at https://icom. museum/en/resources/standards-guidelines/code-of-ethics/.

ICZN (International Commission on Zoological Nomenclature) [Ride, W.D.L., H.G. Cogger, C. Dupuis, O. Kraus, A. Minelli, F.C. Thompson, P.K. Tubbs], eds. 1999. International Code of Zoological Nomenclature. Fourth edition, adopted by the International Union of Biological Sciences (The provisions of this Code supersede those of the previous editions with effect from 1 January 2000). London: International Trust for Zoological Nomenclature. Accessed May 03, 2020 at https://www.iczn.org/ the-code/the-international-code-of-zoological-nomenclature/ the-code-online.

Jagt, J.W.M. 1999. Late Cretaceous-Early Palaeogene echinoderms and the K/T boundary in the southeast Netherlands and northeast Belgium-Part 2: Crinoids. Scripta Geologica 116: 59-255.

Jagt, J.W.M. 2000a. Late Cretaceous-Early Palaeogene echinoderms and the $\mathrm{K} / \mathrm{T}$ boundary in the southeast Netherlands and northeast Belgium-Part 3: Ophiuroids. With a chapter on: Early Maastrichtian ophiuroids from Rügen (northeast Germany) and Møn (Denmark) by Manfred Kutscher and John W.M Jagt. Scripta Geologica 121: 1-179.

Jagt, J.W.M. 2000b. Late Cretaceous-Early Palaeogene echinoderms and the $\mathrm{K} / \mathrm{T}$ boundary in the southeast Netherlands and northeast Belgium-Part 4: Echinoids. Scripta Geologica 121: 181-375.

Jagt, J.W.M. 2000c. Late Cretaceous-Early Palaeogene echinoderms and the $\mathrm{K} / \mathrm{T}$ boundary in the southeast Netherlands and northeast Belgium-Part 5: Asteroids. Scripta Geologica 121: 377-503.

Jagt, J.W.M. 2000d. Late Cretaceous-Early Palaeogene echinoderms and the $\mathrm{K} / \mathrm{T}$ boundary in the southeast Netherlands and northeast Belgium-Part 6: Conclusions. Scripta Geologica 121: 505-577.

Jagt, J.W.M., and E.A. Jagt-Yazykova. 2019. Late Cretaceous and Cenozoic cephalopods from the southern North Sea Basin: stocktaking and future directions. Vita Malacologica 18: 1-33.

Jagt, J.W.M., J. Jackson, and R.W.J.M. van der Ham. 2014. Bathysalenia skylari, a new late Turonian (Late Cretaceous) saleniid echinoid from central Texas, USA. Cretaceous Research 51: 70-74. https://doi.org/10.1016/j.cretres.2014.05.012.

Jagt, J.W.M., B.W.M. van Bakel, B.W.M., M.J.M. Deckers, S.K. Donovan, R.H.B. Fraaije, E.A. Jagt-Yazykova, J. Laffineur, E. Nieuwenhuis, and B. Thijs. 2018. Late Cretaceous echinoderm 'odds and ends' from the Low Countries. Contemporary Trends in Geosciences 7: 255-282.

Jakobsen, S.L. 1991. Ein neues Gesetz schützt fossile Schätze in Dänemark. Fossilien 8(4): 215-220.

Jakobsen, S.L., R.H.B. Fraaije, J.W.M. Jagt, and B.W.M. van Bakel. 2020. New early Paleocene (Danian) paguroids from deepwater coral/bryozoan mounds at Faxe, eastern Denmark. Geologija 63: 47-56.

Jambura, P.L., C. Pfaff, C.J. Underwood, D. Ward, and J. Kriwet. 2018. Tooth mineralization and histology patterns in extinct and extant snaggletooth sharks, Hemipristis (Carcharhiniformes, Hemigaleidae)—evolutionary significance or 
ecological adaptation? PLOS ONE 13: e0200951. https://doi. org/10.1371/journal.pone.0200951.

Jambura, P.L., R. Kindlimann, G. Marramà, C. Pfaff, S. Stumpf, J. Türtscher, C.J. Underwood, D.J. Ward, and J. Kriwet. 2019. Micro-computed tomography imaging reveals the development of a unique tooth mineralization pattern in mackerel sharks (Chondrichthyes; Lamniformes) in deep time. Scientific Reports 9: 9652. https://doi.org/10.1038/s41598-019-46081-3.

Jambura, P.L., J. Türtscher, J. Kriwet, and S.A.A. Al Mabruk. 2020, in review. Whip against Sword - interspecific aggression between the swordfish Xiphias gladius and the bigeye thresher shark Alopias superciliosus. Environmental Biology of Fishes. .

Jansen, U., and F.F. Steininger. 2002. Die paläontologischen Sammlungen in Deutschland: Inhalte, Erfassung und Gefährdung, 1-101. Stuttgart: E. Schweizerbart. (=Kleine Senckenberg-Reihe 42).

Jarvik, E. 1942. On the structure of the snout of crossopterygians and lower gnathostomes in general. Zoologiska Bidrag från Uppsala 21: 235-675.

Jarvik, E. 1954. On the visceral skeleton in Eusthenopteron with a discussion of the parasphenoid and palatoquadrate in fishes. Kungliga Svenska Vetenskapsakademiens Handlingar (4) 5(1): 1-104.

Jenny, D., D. Fuchs, A.I. Arkhipkin, R.B. Hauff, B. Fritschi, and C. Klug. 2019. Predatory behavior and taphonomy of a Jurassic belemnoid coleoid (Diplobelida, Cephalopoda). Scientific Reports 9: 7944. https://doi.org/10.1038/s41598-019-44260-w.

Kaplan, U., W.J. Kennedy, and C.W. Wright. 1987. Turonian and Coniacian Scaphitidae from England and North-Western Germany. Geologisches Jahrbuch (A: Allgemeine und regionale Geologie BR Deutschland und Nachbargebiete, Tektonik, Stratigraphie, Paläontologie) 103: 1-39.

Kelber, K.-P. 2019. Naiadita lanceolata (Marchantiophyta) from the Middle Triassic (Ladinian) of Germany: a new recnstruction attempt and considerations on taphonomy. PalZ. Paläontologische Zeitschrift 93(3): 499-515. https://doi.org/10.1007/s1254 2-019-00484-9.

Kerp, J.H.F. 1982. Aspects of Permian palaeobotany and palynology. II. On the presence of the ovuliferous organ Autunia milleryensis (Renault) Krasser (Peltaspermaceae) in the Lower Permian of the Nahe area and its relationship to Callipteris conferta (Sternberg) Brongniart. Acta Botanica Neerlandica 31: 417-427. https://doi. org/10.1111/j.1438-8677.1982.tb01659.x.

Kerp, J.H.F. 1988. Aspects of Permian palaeobotany and palynology. $\mathrm{X}$. The West- and Central European species of the genus Autunia Krasser emend. Kerp (Peltaspermaceae) and the form-genus Rhachiphyllum Kerp (callipterid foliage). Review of Palaeobotany and Palynology 54: 249-360. https://doi.org/10.1016/00346667(88)90017-6.

Kerp, H., and J. Fichter. 1985. Die Makrofloren des saarpfälzischen Rotliegenden (?Ober-Karbon - Unter-Perm; SW-Deutschland). Mainzer Geowissenschaftliche Mitteilungen 14: 159-286.

Kerp, H., R. Noll, and D. Uhl. 2007a. Übersicht über Pflanzengruppen und Vegetationsentwicklung im Permokarbon des SaarNahe-Becken. In Kohlesümpfe, Seen und Halbwüsten, eds. T. Schindler, and U.H.J. Heidtke. Pollichia, Sonderveröffentlichungen 10: 42-75.

Kerp, H., R. Noll, and D. Uhl. 2007b. Vegetationsbilder aus dem saarpfälzischen Permokarbon. In Kohlesümpfe, Seen und Halbwüsten, eds. T. Schindler, and U.H.J. Heidtke. Pollichia, Sonderveröffentlichungen 10: 76-109.

Keupp, H., and K. Mahlow. 2017. Eine neue Isopoden-Art (Palaega johannschoberti n. sp.) aus dem Amaltheenton (Unter-Jura, Ober-Pliensbachium) von Buttenheim in Oberfranken. Zitteliana 89: 161-170.

Kirejtshuk, A.G. 2020. Taxonomic review of fossil coleopterous families (Insecta, Coleoptera). Suborder Archostemata:
Superfamilies Coleopseoidea and Cupedoidea. Geosciences 10: 73. https://doi.org/10.3390/geosciences 10020073.

Klein, N., and P.C.H. Albers. 2009. A new species of the sauropsid reptile Nothosaurus from the Lower Muschelkalk of the western Germanic Basin, Winterswijk, The Netherlands. Acta Palaeontologica Polonica 54(4): 589-598.

Klein, N., and T.M. Scheyer. 2014. A new placodont sauropterygian from the Middle Triassic of the Netherlands. Acta Palaeontologica Polonica 59(4): 887-902.

Klug, C., and T. Bolliger. 2012. Die fossilen Haie des René Kindlimann. Fossilien 29(6): 372-378.

Knoll, H. 2010. Die Aachener Oberkreide und ihre Pflanzenfossilien. Documenta naturae 58: 1-39.

Košták, M., J.W.M. Jagt, and J. Schlögl. 2019. Diversity and distribution of Miocene-Pliocene sepiids (Cephalopoda) in the Mediterranean area, with new records from Italy and Turkey. In Cephalopods through time, eds. C. Klug, R.T. Becker, A. El Kassani, K. Ritterbusch, D. Fuchs, and D. Marty. Swiss Journal of Palaeontology 138: 99-108.

Kriwet, J., H. Mewis, and O. Hampe. 2015. A partial skeleton of a new mackerel shark (Chondrichthyes, Lamniformes) from the Miocene of Europe. Acta Palaeontologica Polonica 60(4): 857-875.

Krueger, H.-H. 1972. Nachweis der Trilobitengattung Raymondella in Geschieben. Geologie 21(7): 856-858.

Krueger, H.-H. 2004. Die Gattung Erratencrinurus Krueger, 1971 (Trilobita; Ordovizium) aus baltoskandischen Geschieben. Fossil Record 7(1): 69-132. https://doi.org/10.1002/mmng.20040 070106.

Kutscher, M. 1978. Neue Echiniden aus dem Unter-Maastricht der Insel Rügen. I. Holasteridae Durham \& Melville. Zeitschrift für geologische Wissenschaften 6(5): 627-639.

Kutscher, M. 1999. Bernstein, 1-64. Sassnitz: Verein der Freunde und Förderer des Nationalparkes Jasmund e.V.

Kutscher, M., and J. Koteja. 2000. Coccids and aphids [Hemiptera: Coccinea, Aphidinea], prey of ants [Hymenoptera: Formicidae]: evidence from Bitterfeld amber. Polskie Pismo Entomologiczne [=Polish Journal of Entomology] 69(2): 179-194.

Kutscher, M., and L. Villier. 2003. Ophiuroid remains from the Toarcian of Sainte-Verge (Seux-Sèvres, France): paleobiological perspectives. Geobios 36(2): 179-194. https://doi.org/10.1016/ S0016-6995(03)00005-6.

Landesstelle für die nichtstaatlichen Museen in Bayern. 2020. Die Landesstelle, Accessed May 03, 2020 at https://www.museen-inbayern.de/die-landesstelle/die-landesstelle.html.

Lausberg, S., R. Noll, and H. Kerp. 2003. Die Floren der Rhyolithischen Tuffserien im Rotliegend des Saar-Nahe-Beckens: Olsbrücken (RT II) - The floras of the Rhyolithic Tuff Series in the Rotliegend of Saar Nahe Basin: Olsbrücken (RT II). Neues Jahrbuch für Geologie und Paläontologie, Abhandlungen 227(1): 63-92. https://doi.org/10.1127/njgpa/227/2003/63.

Lehmann, J. 2003. Verleihung der Karl-Alfred-von-Zittel-Medaille der Paläontologischen Gesellschaft 2003 an Herbert Menzel. GMit. Geowissenschaftliche Mitteilungen 14: 90-92.

Lindgren, J., P.J. Currie, J. Rees, M. Siverson, S. Lindström, and C. Alwmark. 2008. Theropod dinosaur teeth from the lowermost Cretaceous Rabekke Formation on Bornholm, Denmark. Geobios 41(2): 253-262. https://doi.org/10.1016/j.geobios.2007.05.001.

Lindgren, J., P. Sjövall, V. Thiel, W. Zheng, S. Ito, K. Wakamatsu, R. Hauff, B.P. Kear, A. Engdahl, C. Alwmark, M.E. Eriksson, M. Jarenmark, S. Sachs, P.E. Ahlberg, F. Marone, T. Kuriyama, O. Gustafsson, P. Malmberg, A. Thomen, I. Rodríguez-Meizoso, P. Uvdal, M. Ojika, and M.H. Schweitzer. 2018. Soft-tissue evidence for homeothermy and crypsis in a Jurassic ichthyosaur. Nature 564(7736): 359-365. https://doi.org/10.1038/s4158 6-018-0775-x. 
Linnaeus, C. 1758. Systema natura per regna tria natura, secundum classes, ordines, genera, species, cum characteribus, differentiis, synonymis, locis, Tomus I. 10th ed., 1-823. Holmiæ [=Stockholm]: Laurentius Salvius.

Liston, J. 2016. 'Fossillegal': a symposium on ethics in palaeontology. European Association of Vertebrate Palaeontologists. Newsletter of the Palaeontological Association 93: 27-30.

Lucas, S.G., and J.D. Harris. 2020. The "plastotype problem" in ichnological taxonomy. Ichnos 27(2): 107-110. https://doi. org/10.1080/10420940.2019.1688802.

Lynch, L.I., J.M. Dauer, W.A. Babchuk, T. Heng-Moss, and D. Golick. 2018. In their own words: the significance of participant perceptions in assessing entomology citizen science learning outcomes using a mixed methods approach. Insects 9: 1-16. https://doi. org/10.3390/insects9010016.

MacFadden, B.J., L. Lundgren, K. Crippen, B.A. Dunckel, and S. Ellis. 2016. Amateur paleontological societies and fossil clubs, interactions with professional paleontologists, and social paleontology in the United States. Palaeontologia Electronica 19.2.1E: 1-19. https://doi.org/10.26879/161E.

Makarkin, V.N., and C. Gröhn. 2020. The first unusual Hemerobiidae (Neuroptera) from mid-Cretaceous Burmese amber. Cretaceous Research. https://doi.org/10.1016/j.cretres.2019.104206.

Martin, J.E., J.A. Case, J.W.M. Jagt, A.S. Schulp, and E.W.A. Mulder. 2005. A new European marsupial indicates a Late Cretaceous high-latitude transatlantic dispersal route. Journal of Mammalian Evolution 12: 495-511.

Menzel, H., J.D. Becker-Platen, and L. Benda. 1982. Otolithen aus dem Tertiär der Türkei. In Känozoikum und Braunkohlen der Türkei, 24. Aufbau und Alter des Neogens von Katerini (Griechenland). Geologisches Jahrbuch (B: Regionale Geologie Ausland) 42: $1-101$.

Micklich, N. 2001. Die Sammlung Behnke und der Ameisenbär Eurotamandua joresi-herausragende Fossilien-Funde der Grube Messel. KulturStiftung der Länder-Patrimonia 211: 1-69.

Mol, D., A. Tikhonov, J. van der Plicht, R.-D. Kahlke, R. Debruyne, B. van Geel, G. Reenen, J.P. Pals, C. de Marliave, and J.W.F. Reumer. 2006. Results of the CERPOLEX/Mammuthus Expeditions on the Taimyr Peninsula, Arctic Siberia, Russian Federation. Quaternary International 142(143): 186-202. https://doi. org/10.1016/j.quaint.2005.03.016.

Mollen, F.H., S.P. Wintner, S.P. Iglésias, S.R. van Sommeran, and J.W.M. Jagt. 2012. Comparative morphology of rostral cartilages in extant mackerel sharks (Chondrichthyes, Lamniformes, Lamnidae) using CT scanning. Zootaxa 3340: 29-43.

Mulder, E.W.A., P. Formanoy, W.B. Gallagher, J.W.M. Jagt, and A.S. Schulp. 2013. The first North American record of Carinodens belgicus (Squamata, Mosasauridae) and correlation with the youngest in situ examples from the Maastrichtian type area: palaeoecological implications. In The Sunday's child of Dutch earth sciences-a tribute to Bert Boekschoten on the occasion of his 80th birthday, eds. E.W.A. Mulder, J.W.M. Jagt, and A.S. Schulp. The Netherlands Journal of Geosciences 92: 145-152.

Mundlos, R. 1973. Ist Conchorhynchus ein Ceratiten-Kiefer? Paläontologische Zeitschrift 47(3-4): 156-162. https://doi.org/10.1007/ BF02985704.

myFossil. 2020. Social paleontology, accessed May 18, 2020 at https ://myfossil.org.

Nagler, C., C. Haug, U. Resch, J. Kriwet, and J.T. Haug. 2016. A 150 million years old "very hungry caterpillar": first fossil record of cymothoid isopods parasitizing on fishes. Bulletin of Geosciences 91: $1-12$.

Neenan, J.M., N. Klein, and T.M. Scheyer. 2013. European origin of placodont marine reptiles and the evolution of crushing dentition in Placodontia. Nature Communications 4: 1621. https://doi. org/10.1038/ncomms2633.
Neregato, R., R. Rößler, R. Rohn, and R. Noll. 2015. New petrified calamitaleans from the Permian of the Parnaíba Basin, centralnorth Brazil. Part I. Review of Palaeobotany and Palynology 215: 23-45. https://doi.org/10.1016/j.revpalbo.2014.12.006.

ÖPG (Österreichische Paläontologische Gesellschaft). 2020. Willkommen auf der Homepage der Österreichischen Paläontologischen Gesellschaft, Accessed May 18, 2020 at https://fossils-of-austr ia.at.

Ouden, N. den, and R. Pouwer. 2018. Professional and amateur palaeontologists-the Dutch Polder Model. The Geological Curator 10(10): 577-584.

Pascual-Cebrian, E., D.K. Hennhöfer, and S. Götz. 2013. 3D morphometry of polyconitid rudist bivalves based on grinding tomography. Facies 59: 347-358. https://doi.org/10.1007/s10347-012-0310-8.

PalGes (Paläontologische Gesellschaft). 2020. Fossilien sammeln, Accessed May 18, 2020 at https://www.palaeontologische-gesel 1schaft.de/palaeontologie/sammeln/

Pazinato, P.G., C. Jauvion, G. Schweigert, J.T. Haug, and C. Haug. 2020, Early view. After 100 years: a detailed view of an eumalacostracan crustacean from the Upper Jurassic Solnhofen Lagerstätte with raptorial appendages unique to Euarthropoda. Lethaia.https://doi.org/10.1111/let.12382.

Perez, V.J., R.M. Leder, L. Lundgren, S. Ellis, B. Dunckel, and K. Crippen. 2020. The Belgrade PaleoBlitz: A pilot project to engage amateur paleontologists. Palaeontologia Electronica 23(1): a18. https://doi.org/10.26879/1013palaeo-electronica.org/conte nt/2020/3009-paleontology-citizen-science.

Pollerspöck, J., C.K. Flammensbeck, and N. Straube. 2018. Palaeocentroscymnus (Chondrichthyes: Somniosidae), a new sleeper shark genus from Miocene deposits of Austria (Europe). PalZ. Paläontologische Zeitschrift 92(3): 443-456. https://doi.org/10.1007/ s12542-017-0398-9.

Quenstedt, F.A. 1835. Ueber die Enkriniten des Muschelkalkes. Archiv für Naturgeschichte 1(2)[2]: 223-228.

Rauhut, O.W.M. 2018. Publish before they perish: dealing with privately-owned specimens in palaeontology. The Geological Curator 10(10): 561-564.

Rauhut, O.W.M., C. Foth, H. Tischlinger, and M.A. Norell. 2012. Exceptionally preserved juvenile megalosauroid theropod dinosaur with filamentous integument from the Late Jurassic of Germany. Proceedings of the National Academy of Sciences 109(29): 11746-11751. https://doi.org/10.1073/pnas.1203238109.

Rauhut, O.W.M., A. López-Arbarello, and G. Wörheide. 2014. Private collections of fossils are a plus. Nature 512(7515): 371. https:// doi.org/10.1038/512371c.

Rauhut, O.W.M., C. Foth, and H. Tischlinger. 2018. The oldest Archaeopteryx (Theropoda: Avialiae): a new specimen from the Kimmeridgian/Tithonian boundary of Schamhaupten, Bavaria. PeerJ 6: e4191. https://doi.org/10.7717/peerj.4191.

Rayfield, E.J., J.M. Theodor, and P.D. Polly. 2020. Fossils from conflict zones and reproducibility of fossil-based scientific data. Society of Vertebrate Paleontology, letter, 21/04/2020. https:// vertpaleo.org/Society-News/SVP-Paleo-News/Society-News,Press-Releases/On-Burmese-Amber-and-Fossil-RepositoriesSVP-Memb.aspxhttps://vertpaleo.org/GlobalPDFS/SVP-Lette r-to-Editors-FINAL.aspx

Reich, M. 2001. Zittel-Medaille für Manfred Kutscher. Geschiebekunde aktuell 17: 74.

Reich, M. 2008a. Die Bernsteinsammlung M. Kutscher and der Universität Göttingen. In Bitterfelder Bernstein versus Baltischer Bernstein. Hypothesen, Fakten, Fragen. II. Bitterfelder Bernsteinkolloquium, eds. J. Rascher, R. Wimmer, G. Krumbiegel, and S. Schmiedel. Exkursionsführer und Veröffentlichungen der Deutschen Gesellschaft für Geowissenschaften (DGG) 236: 136 . 
Reich, M. 2008b. The Value of the Göttingen Geoscientific Collections for Biodiversity and Palaeobiodiversity Research. GCBE Bulletin. Nachrichtenheft des Göttinger Zentrums für Biodoversitätsforschung und Ökologie 1/2007: 31-36.

Reich, M., and G. Wörheide. 2018. München: The Fossil Collections of the Bavarian State Collections at Munich. In Paleontological Collections of Germany, Austria and Switzerland, eds. L.A. Beck, and U. Joger, 427-443. Heidelberg etc.: Springer. https:// doi.org/10.1007/978-3-319-77401-5_43.

Reich, M., B. Ilsemann, and M. Krings. 2019. Faszination Bernstein. Momentaufnahmen aus einer vergangenen Zeit/Fascination Amber. Snapshots from the Distant Past. 1-60. München: BSPG.

Reumer, J.W.F., L. Rook, K. van der Borg, K. Post, D. Mol, and J. de Vos. 2003. Late Pleistocene survival of the sabre-toothed cat Homotherium in Northwestern Europe. Journal of Vertebrate Paleontology 23(1): 260-262. https://doi.org/10.1671/02724634(2003)23[260:LPSOTS]2.0.CO;2.

Reumer, J.W.F., D. Mol, and R.-D. Kahlke. 2018. First finds of Pleistocene Macaca sylvanus (Cercopithecidae, Primates) from the North Sea. Revue de Paléobiologie 37: 555-560. https://doi. org/10.5281/zenodo.2545095.

Reumer, J.W.F., J. Mulder, E.W. Mulder, H. Akkerman, and J.H. van Konijnenburg-van Cittert. 2020. The Rhaetian/Hettangian dipterid fern Clathropteris meniscioides Brongniart found in erratics in the eastern Netherlands and adjacent Germany. Neues Jahrbuch für Geologie und Paläontologie, Abhandlungen 295: 297-306. https://doi.org/10.1127/njgpa/2020/0888.

Rhebergen, F., and J.P. Botting. 2014. A new Silurian (Llandovery, Telychian) sponge assemblage from Gotland, Sweden. Fossils and Strata 60: 1-87.

Rhebergen, F., and U. van Hacht. 2000. Ordovician erratic sponges from Gotland, Sweden. GFF 122(4): 339-349. https://doi. org/10.1080/11035890001224339.

Rievers, J. 1961. Eine neue Pyrgocystis (Echinod.Edrioasteroidea) aus den Bundenbacher Dachschiefern Devon. Mitteilungen der Bayerischen Staatssammlung für Paläontologie und historische Geologie 1: 9-11.

Rößler, R., and R. Noll. 2006. Sphenopsids of the Permian (I): The largest known anatomically preserved calamite, an exceptional find from the petrified forest of Chemnitz, Germany. Review of Palaeobotany and Palynology 140: 145-162. https://doi. org/10.1016/j.revpalbo.2006.03.008.

Rößler, R., and R. Noll. 2010. Anatomy and branching of Arthropitys bistriata (Cotta) Goeppert - New observations from the Permian petrified forest of Chemnitz, Germany. International Journal of Coal Geology 83: 103-124. https://doi.org/10.1016/j. coal.2009.07.011.

Rößler, R., Z. Feng, and R. Noll. 2012. The largest calamite and its growth architecture-Arthropitys bistriata from the Early Permian Petrified Forest of Chemnitz. Review of Palaeobotany and Palynology 185: 64-78. https://doi.org/10.1016/j.revpa lbo.2012.07.018.

Rößler, R., M. Merbitz, V. Annacker, L. Luthardt, R. Noll, R. Neregato, and R. Rohn. 2014. The root systems of Permian arborescent sphenopsids: evidence from the Northern and Southern hemispheres. Palaeontographica (B: Paläophytologie) 291(4-6): 65-107.

Sachs, S., B.P. Kear, and M.J. Everhart. 2013. Revised vertebral count in the "longest-necked vertebrate" Elasmosaurus platyurus Cope 1868 , and clarification of the cervical-dorsal transition in Plesiosauria. PLoS ONE 8(8): e70877. https://doi.org/10.1371/journ al.pone. 0070877 .

Schädel, M., T. van Eldijk, H. Winkelhorst, J.W.F. Reumer, and J.T. Haug. 2020. Triassic Isopoda-three new species from Central Europe shed light on the early diversity of the group. Bulletin of Geosciences.https://doi.org/10.3140/bull.geosci.1773.
Schroeder, R. 1991. Adolf Franke und Joseph A. Cushman - ein unbekanntes Kapitel aus der Geschichte der deutschen Mikropaläontologie. Geologisches Jahrbuch (A: Allgemeine und regionale Geologie BR Deutschland und Nachbargebiete, Tektonik, Stratigraphie, Paläontologie) 128: 17-34.

Schweitzer, C.E., R.M. Feldmann, and M.M. Schinker. 2019. A new species of Cyclida (Multicrustacea; Halicynidae) from the Triassic of The Netherlands. Neues Jahrbuch für Geologie und Paläontologie, Abhandlungen 293(1): 67-71. https://doi. org/10.1127/njgpa/2019/0831.

Selden, P.A., and W.A. Shear. 1996. The first Mesozoic Solifugae (Arachnida) from the Cretaceous of Brazil, and a redescription of Palaeozoic solifuge. Palaeontology 39(3): 583-604.

Shabica, C.W., and A.A. Hay (eds.). 1997. Richardson's Guide to the Fossil Fauna of Mazon Creek, xvii + 1-308. Chicago: Northeastern Illinois University.

Siber, H.J., and U. Möckli. 2009. The stegosaurs of the Sauriermuseum Aathal. Aathal: Sauriermuseum Aathal.

Siveter, D.J., D.E.G. Briggs, D.J. Siveter, and M.D. Sutton. 2020. The Herefordshire Lagerstätte: fleshing out Silurian marine life. Journal of the Geological Society 177: 1-13. https://doi.org/10.1144/ jgs2019-110.

Slater, T.S., K. Ashbrook, and J. Kriwet. 2020. Interrelationships of bullhead sharks (Chondrichthyes: Heterodontiformes) and implications for the extinction of the Jurassic heterodontiform, $\dagger$ Paracestracion. Papers in Palaeontology.https://doi.org/10.1002/ spp2.1299.

Smithson, T.R., and W.D.I. Rolfe. 2018. What made Stan Wood a great collector? Earth and Environmental Science Transactions of the Royal Society of Edinburgh 108(1): 7-17. https://doi. org/10.1017/S1755691018000154.

Struve, W. 1967. Zur Geschichte der Paläozoologisch-Geologischen Abteilung des Natur-Museums und Forschungs-Instituts Senckenberg. Teil 1: Von 1763 bis 1907. Senckenbergiana lethaea 48(A): 23-191.

Stumpf, S., U. Scheer, and J. Kriwet. 2019. A new genus and species of extinct ground sharks, $\dagger$ Diprosopovenator hilperti gen. et. sp. nov. (Carcharhiniformes, †Pseudoscyliorhinidae fam. nov.), from the Late Cretaceous of Germany. Journal of Vertebrate Paleontology 39: e1593185. https://doi.org/10.1080/02724 634.2019.1593185.

Switek, B. 2013. Historical fossils may be lost at auction. National Geographic of 14th November 2013, with update of 18th November 2013, Accessed June 3, 2020 at https://www.nationalgeograp hic.com/science/phenomena/2013/11/14/historical-fossils-maybe-lost-at-auction/

Szwedo, J., and E. Sontag. 2015. Is the amber inclusions trade jeopardizing scientific research? In Amber news review 2014/2015, World Amber Council, Gdańsk, Poland, 2015, eds. R. Pytlos, R. Szadziewski, A. Zbierska, A. Adamska, and A. Dmowska, 29-43. Gdańsk: Mayor's Office for City Promotion, City Hall of Gdańsk.

Tajika, A., N.H. Landman, R. Hoffmann, R. Lemanis, N. Morimoto, C. Ifrim, and C. Klug. 2020. Metabolic rates in modern and fossil cephalopods as a factor of selective extinction. Scientific Reports 10: 295. https://doi.org/10.1038/s41598-020-59748-z.

Tavares, T.M.V., R. Rohn, R. Rößler, and R. Noll. 2014. Petrified marattiales pinnae from the Lower Permian of north-western Gondwana (Parnaíba Basin, Brazil). Review of Palaeobotany and Palynology 201: 12-28. https://doi.org/10.1016/j.revpa lbo.2013.09.002.

Thuy, B., A.A. Klompmaker, and J.W.M. Jagt. 2012. Late Triassic (Rhaetian) ophiuroids from Winterswijk, the Netherlands, with comments on the systematic position of Aplocoma (Echinodermata, Ophiolepididae). In Echinoderm Research 2010: Proceedings of the Seventh European Conference on Echinoderms, 
Göttingen, Germany, 2-9 October 2010, eds. A. Kroh, and M. Reich. Zoosymposia 7: 163-172.

Thuy, B., L.D. Numberger-Thuy, and J.W.M. Jagt. 2018. An unusual assemblage of ophiuroids (Echinodermata) from the late Maastrichtian of South Carolina, USA. In Special Issue: Hans Hess: A lifelong passion for fossil echinoderms, eds. C.A. Meyer, B. Thuy, C. Klug, D. Marty, and S.K. Donovan. Swiss Journal of Palaeontology 137: 337-356. https://doi.org/10.1007/s1335 8-018-0166-9.

Tischlinger, H., and G. Arratia. 2013. Ultraviolet light as a tool for investigating Mesozoic fishes, with a focus on the ichthyofauna of the Solnhofen archipelago. In Mesozoic fishes 5-global diversity and evolution, eds. G. Arratia, H.-P. Schultze, and M.V.H. Wilson, 549-560. München: F. Pfeil.

Tschirnhaus, M. von, and C. Hoffeins. 2009. Fossil flies in Baltic amber-insights in the diversity of Tertiary Acalyptratae (Diptera, Schizophora), with new morphological characters and a key based on 1,000 collected inclusions. Denisia 26: 171-212. (=Kataloge der oberösterreichischen Landesmuseen, Neue Serie 86).

Turland, N.J., J.H. Wiersema, F.R. Barrie, W. Greuter, D.L. Hawksworth, P.S. Herendeen, S. Knapp, W.-H. Kusber, De-zhu Li,
K. Marhold, T.W. May, J. McNeill, A.M. Monro, J. Prado, M.J. Price, and G.F. Smith, eds. 2018. International Code of Nomenclature for algae, fungi, and plants (Shenzhen Code), adopted by the Nineteenth International Botanical Congress Shenzhen, China, July 2017. Regnum Vegetabile 159: xxxviii + 1-254. https ://doi.org/10.12705/Code.2018.

Uhl, D., S. Lausberg, R. Noll, and K.R.G. Stapf. 2004. Wildfires in the Late Palaeozoic of Central Europe - an overview of the Rotliegend (Upper Carboniferous-Lower Permian) of the SaarNahe Basin (SW-Germany). Palaeogeography Palaeoclimatology Palaeoecology 207: 23-35. https://doi.org/10.1016/j.palae o.2004.01.019.

Wiffen, J. 1991. Valley of the dragons: the story of New Zealand's dinosaur woman, 1-128. Auckland: Random Century.

Zherikhin, V.V., A.G. Ponomarenko, and A.P. Rasnitsyn. 2008. Kratkaya istoriya paleoentomologii [Short history of palaeoentomology]. In Vvedenie $v$ paleoentomologiyu [Introduction to palaeoentomology], V.V. Zherikhin, A.G. Ponomarenko, and A.P. Rasnitsyn, 100-119. Moscow: KMK Press.

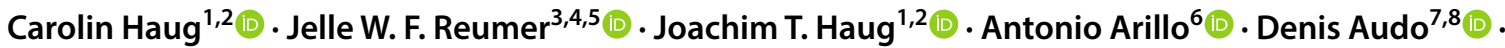
Dany Azar ${ }^{9}$ (i) - Viktor Baranov ${ }^{1}$ (D) - Rolf Beutel ${ }^{10}$ (D) . Sylvain Charbonnier ${ }^{11} \cdot$ Rodney Feldmann $^{12} \cdot$ Christian Foth $^{13}$ (D) René H. B. Fraaije ${ }^{14}(\mathbb{1})$. Peter Frenzel ${ }^{15}$ (i) . Rok Gašparič ${ }^{14,16}$ (D) Dale E. Greenwalt ${ }^{17}$. Danilo Harms ${ }^{45}$.

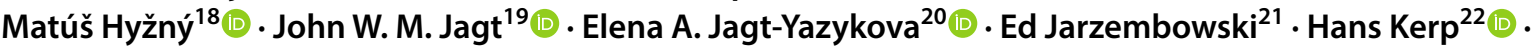

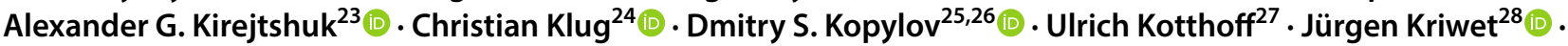

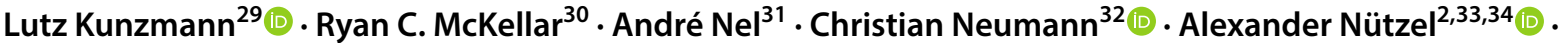
Vincent Perrichot ${ }^{35}$ (1) - Anna Pint ${ }^{36}$. Oliver Rauhut ${ }^{2,33,34}$ - Jörg W. Schneider ${ }^{37,38}$ - Frederick R. Schram ${ }^{39}$ (1)

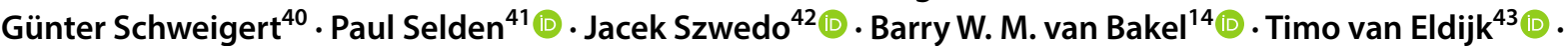

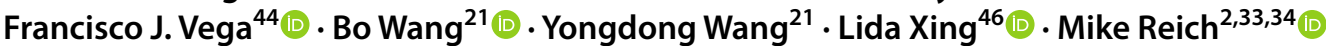

1 Department of Biology II, Ludwig-MaximiliansUniversität München, Großhaderner Straße 2, 82152 Planegg-Martinsried, Germany

2 GeoBio-Center, Ludwig-Maximilians-Universität München, Richard-Wagner-Str. 10, 80333 Munich, Germany

3 Department of Earth Sciences, Utrecht University, P.O. Box 80.115, 3508 TC Utrecht, The Netherlands

4 Naturalis Biodiversity Center, P.O. Box 9517, 2300 RA Leiden, The Netherlands

5 Natural History Museum Rotterdam, Westzeedijk 345, 3015 AA Rotterdam, The Netherlands

6 Departamento de Biodiversidad, Ecología y Evolución, Facultad de Biología, Universidad Complutense, 28040 Madrid, Spain

7 Yunnan Key Laboratory for Palaeobiology, Yunnan University, Kunming 650500, China

8 MEC International Joint Laboratory for Palaeobiology and Palaeoenvironment, Yunnan University, Kunming 650500, China

9 Department of Natural Sciences, Faculty of Sciences II, Lebanese University, P.O. Box: 26110217, Fanar-Matn, Lebanon
10 Institut für Zoologie und Evolutionsforschung, FSU Jena, Erbertstrasse 1, 07743 Jena, Germany

11 Centre de Recherche en Paléontologie - Paris (CR2P, UMR 7207), (CNRS, MNHN, Sorbonne Université), Muséum national d'Histoire naturelle, Case postale 38, 57 rue Cuvier, 75231 Paris Cedex 05, France

12 Department of Geology, Kent State University, Kent, OH 44242, USA

13 Department of Geosciences, Université de Fribourg, Chemin du Musée 6, 1700 Fribourg, Switzerland

14 Oertijdmuseum, Bosscheweg 80, 5283 WB Boxtel, The Netherlands

15 Allgemeine und Historische Geologie, Institut für Geowissenschaften, Friedrich-Schiller-Universität Jena, Burgweg 11, 07749 Jena, Germany

16 Novi trg 59, 1241 Kamnik, Slovenia

17 Department of Paleobiology, National Museum of Natural History MRC 121, Smithsonian Institution, 10th Street and Constitution Ave. NW, Washington, D.C 20013-7012, USA

18 Department of Geology and Palaeontology, Faculty of Natural Sciences, Comenius University, Mlynská dolina, Ilkovičova 6, 84215 Bratislava, Slovakia 
19 Natuurhistorisch Museum Maastricht, de Bosquetplein 6-7, 6211 KJ Maastricht, The Netherlands

20 Instytut Biologii, Uniwersytet Opolski, ul. Oleska 22, 45-052 Opole, Poland

21 State Key Laboratory of Palaeobiology and Stratigraphy, Nanjing Institute of Geology and Palaeontology and Center for Excellence in Life and Paleoenvironment, Chinese Academy of Sciences, 39 East Beijing Road, Nanjing 210008, China

22 Forschungsstelle für Paläobotanik, Institut für Geologie und Paläontologie, Westfälische Wilhelms-Universität Münster, 48149 Münster, Germany

23 Zoological Institute of Russian Academy of Sciences, Universitetskaya Emb 1, St. Petersburg 199034, Russia

24 Universität Zürich, Paläontologisches Institut und Museum, Karl-Schmid-Strasse 4, 8006 Zürich, Switzerland

25 A.A. Borissiak Palaeontological Institute, Russian Academy of Sciences, Moscow 117647, Russia

26 Cherepovets State University, Cherepovets 162600, Russia

27 Centrum für Naturkunde (CeNak), Universität Hamburg, Geologisch-Paläontologisches Museum und Institut für Geologie, Bundesstrasse 55, 20146 Hamburg, Germany

28 Department of Palaeontology, Faculty of Earth Sciences, Geography and Astronomy, University of Vienna, Palaeobiology and Vertebrate Palaeontology, UZA 2, Geocentre, Althanstr. 14, 1090 Vienna, Austria

29 Senckenberg Natural History Collections Dresden, Museum of Mineralogy and Geology, Königsbrücker Landstr. 159, 01109 Dresden, Germany

30 Royal Saskatchewan Museum, 2340 Albert St, Regina, SK S4P 2V7, Canada

31 Institut de Systématique, Évolution, Biodiversité, ISYEB-UMR 7205, MNHN-CNRS-Sorbonne Université-EPHE, Muséum national d'Histoire naturelle, CP 50, 57 rue Cuvier, 75005 Paris, France

32 Museum für Naturkunde, Leibniz Institute for Evolution and Biodiversity Science, Invalidenstraße 43, 10115 Berlin, Germany
33 SNSB - Bavarian State Collections of Palaeontology and Geology, Richard-Wagner-Str. 10, 80333 Munich, Germany

34 Department of Earth and Environmental Sciences, Ludwig-Maximilians-Universität München, Richard-Wagner-Str. 10, 80333 Munich, Germany

35 UMR 6118, Univ Rennes, CNRS, Géosciences Rennes, 35000 Rennes, France

36 Institute of Geography, University of Cologne, Albertus Magnus Platz, 50931 Cologne, Germany

37 TU Bergakademie Freiberg, Institut für Geologie, Bernhard-von-Cotta-Straße 2, 09596 Freiberg, Germany

38 Institute of Geology and Petroleum Technologies, Kazan Federal University, Kremlyovskaya Street 18, Kazan, Russia

39 Burke Museum, University of Washington, Seattle, 5485 Shadywood Place, Post Box 1567, Langley, WA 98260, USA

40 Palaeontology Department, State Museum of Natural History Stuttgart, Rosenstein 1, 70191 Stuttgart, Germany

41 Department of Geology and Paleontological Institute, University of Kansas, Lindley Hall, 1475 Jayhawk Boulevard, Lawrence, KS 66045, USA

42 Laboratory of Evolutionary Entomology and Museum of Amber Inclusions, Department of Invertebrate Zoology and Parasitology, Faculty of Biology, University of Gdańsk, 59, Wita Stwosza St, 80308 Gdańsk, Poland

43 Groningen Institute for Evolutionary Life Sciences, University of Groningen, Nijenborgh 7, 9747 AG Groningen, The Netherlands

44 Instituto de Geología, Universidad Nacional Autónoma de México, 04510 Coyoacán, CDMX, Mexico

45 Center of Natural History, Zoological Museum, Universität Hamburg, Martin-Luther-King-Platz 3, 20146 Hamburg, Germany

46 School of the Earth Sciences and Resources, China University of Geosciences, Beijing 100083, China 